Document downloaded from:

http://hdl.handle.net/10251/28137

This paper must be cited as:

Bruijnincx Pieter C. A; Buurmans, ILC.; Huang, Y.; Juhász, G.; Viciano-Chumillas, M.; Quesada Vilar, M.; Reedijk, J.... (2011). Mono- and dinuclear iron complexes of bis(1methylimidazol-2-yl)ketone (bik): structure, magnetic properties, and catalytic oxidation studies. Inorganic Chemistry. 9243-9255. doi:10.1021/ic200332y

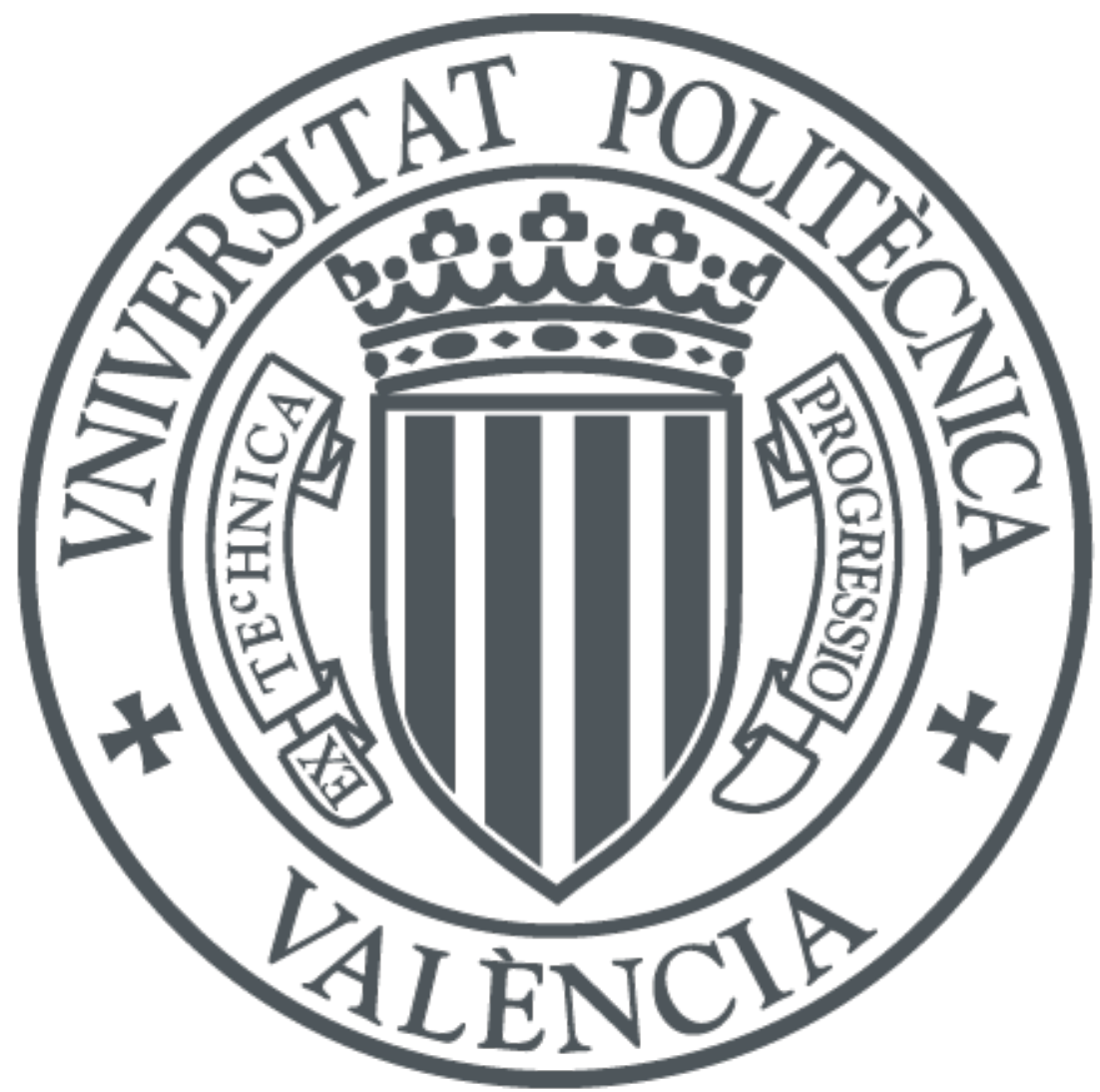

The final publication is available at

http://doi.org/10.1021/ic200332y

Copyright American Chemical Society

Additional Information 


\title{
Mono- and Dinuclear Iron Complexes of Bis(1-methylimidazol-2- yl)ketone (bik): Structure, Magnetic Properties and Catalytic Oxidation Studies
}

\author{
Pieter C. A. Bruijnincx ${ }^{\dagger, \perp}$, Inge L. C. Buurmans ${ }^{\dagger}$, Yuxing Huang ${ }^{\dagger}$, Gergely Juhász ${ }^{\uparrow, \theta}$, Marta \\ Viciano-Chumillas $§$, Manuel Quesada§, Jan Reedijk§,@, Martin Lutz ${ }^{\#}$, Anthony L. Spek ${ }^{\#, \ddagger}$, \\ Eckard Münck ${ }^{\Uparrow}$, Emile L. Bominaar ${ }^{\sharp,}$, , and Robertus J. M. Klein Gebbink ${ }^{\dagger,}$
}

†Organic Chemistry and Catalysis, Debye Institute for Nanomaterials Science, Utrecht University, Padualaan 8, $3584 \mathrm{CH}$ Utrecht, The Netherlands §Leiden Institute of Chemistry, Leiden University, Coordination and Bioinorganic Chemistry Group, P. O. Box 9502, 2300 RA Leiden, The Netherlands @Department of Chemistry, King Saud University, P.O. Box 2455, Riyadh 11451, Saudi Arabia IDepartment of Chemistry, Carnegie Mellon University, Pittsburgh, Pennsylvania 15213, USA \#Bijvoet Center for Biomolecular Research, Crystal and Structural Chemistry, Faculty of Science, Utrecht University, Padualaan 8, $3584 \mathrm{CH}$ Utrecht, The Netherlands

\section{Abstract}

The newly synthesized dinuclear complex $\left[\mathrm{Fe}^{\mathrm{III}}{ }_{2}(\mu-\mathrm{OH})_{2}(\mathbf{b i k})_{4}\right]\left(\mathrm{NO}_{3}\right)_{4}(\mathbf{1})(\mathbf{b i k}$, bis $(\mathbf{1}$ methylimidazol-2-yl)ketone) shows rather short $\mathrm{Fe} \cdots \mathrm{Fe}(3.0723(6) \AA)$ and $\mathrm{Fe}-\mathrm{O}$ distances $(1.941(2) / 1.949(2) \AA)$ compared to other unsupported $\mathrm{Fe}^{\mathrm{III}}{ }_{2}(\mu-\mathrm{OH})_{2}$ complexes. The bridging hydroxide groups of $\mathbf{1}$ are strongly hydrogen bonded to a nitrate anion. The ${ }^{57} \mathrm{Fe}$ isomer shift $(\delta=$ $\left.0.45 \mathrm{~mm} \mathrm{~s}^{-1}\right)$ and quadrupole splitting $\left(\Delta \mathrm{E}_{\mathrm{Q}}=0.26 \mathrm{~mm} \mathrm{~s}^{-1}\right)$ obtained from Mössbauer spectroscopy are consistent with the presence of two identical high-spin iron(III) sites. Variable temperature magnetic susceptibility studies revealed antiferromagnetic exchange $\left(J=35.9 \mathrm{~cm}^{-1}\right.$ and $\mathscr{H}=J \mathbf{S}_{1} \cdot \mathbf{S}_{2}$ ) of the metal ions. The optimized DFT geometry of the cation of $\mathbf{1}$ in the gas phase agrees well with the crystal structure, but both the $\mathrm{Fe} \cdots \mathrm{Fe}$ and $\mathrm{Fe}-\mathrm{OH}$ distances are overestimated (3.281 and $2.034 \AA$, respectively). The agreement in these parameters improves dramatically (3.074 and $1.966 \AA$ ) when the hydrogen-bonded nitrate groups are included, reducing the value calculated for $J$ by $35 \%$. Spontaneous reduction of 1 was observed in methanol, yielding a blue $\left[\mathrm{Fe}^{\mathrm{II}}(\mathrm{bik})_{3}\right]^{2+}$ species. Variable temperature magnetic susceptibility measurements of $\left[\mathrm{Fe}^{\mathrm{II}}(\mathrm{bik})_{3}\right]$ $(\mathrm{OTf})_{2}(\mathbf{2})$ revealed spin crossover behavior. Thermal hysteresis was observed with $\mathbf{2}$, due to a loss of co-crystallized solvent molecules, as monitored by thermogravimetric analysis. The hysteresis disappears once the solvent is fully depleted by thermal cycling. $\left[\mathrm{Fe}^{\mathrm{II}}(\mathrm{bik})_{3}\right](\mathrm{OTf})_{2}(\mathbf{2})$ catalyzes the oxidation of alkanes with $t$-BuOOH. High selectivity for tertiary $\mathrm{C}-\mathrm{H}$ bond oxidation was observed with adamantane $\left(3^{\circ} / 2^{\circ}\right.$ value of 29.6$)$; low alcohol/ketone ratios in cyclohexane and

\footnotetext{
"corresponding authors: R. J. M. Klein Gebbink (phone +31-30-2531889; fax +31-30-2523615), r.j.m.kleingebbink@ chem.uu.nl; and E. L. Bominaar (phone +11-412-268-5671; fax+11-412-268-1061), eb7g@andrew.cmu.edu. ${ }^{\ddagger}$ To whom correspondence pertaining to the crystallographic studies should be addressed: a.1.spek@chem.uu.nl.

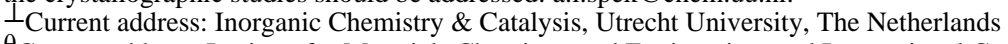

${ }^{\theta}$ Current address: Institute for Materials Chemistry and Engineering, and International Center for Molecular Systems, Kyushu University, Fukuoka, Japan

Supporting Information Available: Cif files of crystal data collection and refinement parameters, atomic coordinates, bond lengths and angles, anisotropic displacement parameters for compounds $\mathbf{1}$ and $\mathbf{2} \cdot \mathbf{M e O H}$; Overlay of optimized DFT geometry and X-ray structure of $\mathbf{1}$, an emperical $J$ vs. $\mathrm{Fe}-\mathrm{O}(\mathrm{H})$, and plots of $\mathrm{Fe}-\mathrm{O}-\mathrm{Fe}$ angles, $\mathrm{Fe}-\mathrm{O}$, and $\mathrm{O}-\mathrm{H}$ distance vs. $\mathrm{Fe} \cdots \mathrm{Fe}$ distance. This material is available free of charge via the internet at http://pubs.acs.org
} 
ethylbenzene oxidation, a strong dependence of total turnover number on the presence of $\mathrm{O}_{2}$, and a low retention of configuration in cis-1,2-dimethylcyclohexane oxidation were observed. Stereoselective oxidation of olefins with dihydrogen peroxide yielding epoxides was observed under both limiting oxidant and substrate conditions.

\section{Introduction}

The development of environmentally friendly catalytic oxidation processes for the selective conversion of hydrocarbons is a topic of continuing interest. ${ }^{1}$ In particular, inspiration for the design of new catalytic systems has been drawn from Nature, where metalloenzymes are often involved in highly selective oxidative transformations under mild conditions. The nonheme iron oxygenases ${ }^{2-5}$ constitute an important and versatile subgroup of these metalloenzymes capable of oxidative transformations. Non-heme iron oxygenases generally feature either a mononuclear or a dinuclear active site. Amongst the mononuclear non-heme iron enzymes, the 2-His-1-carboxylate facial triad has emerged as a common structural motif. 2,3 The oxidative transformations that these enzymes catalyze are very diverse, ranging from the cis-dihydroxylation of arenes by the Rieske dioxygenases to, for example, the dioxygenative cleavage of aromatic substrates by the extradiol cleaving dioxygenases. A particularly well studied example of a dinuclear non-heme iron enzyme is the soluble form of methane monooxygenase, which selectively catalyzes the unique conversion of methane to methanol. ${ }^{5,6}$ Many biomimetic modeling studies have been devoted to these two classes of non-heme iron enzymes. On the one hand, such studies can contribute to the elucidation of structure-activity relationships for the enzymes under scrutiny. For instance, dinuclear iron complexes aid in the understanding of the structural intricacies, such as the magnetic interaction between the metal centers, of the bimetallic active sites. On the other hand, synthetic mono- and dinuclear iron active site analogues serve as potential synthetic oxidation catalysts and their properties have been widely explored also in this respect. Promising examples of mononuclear catalysts capable of alkane hydroxylation, olefin epoxidation, and cis-dihydroxylation have been reported. ${ }^{1,3,5,7-13}$ Ligand systems that are widely used for the construction of both mono- and dinuclear iron complexes include the polydentate tris(2-pyridylmethyl)amine (tpa) and $N, N^{\prime}$-bis(2-pyridylmethyl)- $N, N^{\prime}$ dimethyl-1,2-ethylenediamine ligand family (bpmen), ${ }^{14,15}$ and the $N, N$-bis(2pyridylmethyl)- $N$-bis(2-pyridyl)methylamine (N4py), ${ }^{16,17}$ 2-(2',5'-diazapentyl)-5bromopyrimidine-6-carboxylic acid N-[2,(4'-imidazolyl)ethyl]amide (Hpma), ${ }^{18}$ and tris((1methylimidazol-2-yl)methyl)amine (tmima) ligands, ${ }^{19}$ amongst many others (Figure 1). Efficient dinuclear iron oxidation catalysts were also reported, ${ }^{20}$ some of which with very simple bidentate ligands such as bipyridine (bipy) and phenanthroline (phen). ${ }^{8,21,22}$

As part of our recent efforts to develop biomimetic models of the 2-His-1-carboxylate facial triad, we have reported on the new ligand family of the substituted 3,3-bis(1-

alkylimidazol-2-yl)propionates (parent ligand L1, Figure 1) and their iron complexes. ${ }^{7,23,24}$ $\left[\mathrm{Fe}^{\mathrm{II}}(\operatorname{PrL1})_{2}\right](\mathrm{OTf})_{2}(\operatorname{PrL1}$, propyl 3,3-bis(1-methylimidazol-2-yl)propionate) was found to be an active bio-inspired catalyst for the epoxidation and cis-dihydroxylation of olefins, for instance. ${ }^{7}$ Encouraged by the results obtained with the dinuclear Fe(III) catalysts containing the simple bidentate bipy and phen ligands, we decided to explore the structure and catalytic properties of iron(III) and iron(II) complexes of the ligand bis(1-methylimidazol-2-yl)ketone (bik). This bidentate ligand is used as a building block for the synthesis of $\mathbf{L 1}$ and can be easily synthesized in one step on a multigram scale. ${ }^{25}$ Here, we report the synthesis and structural, spectroscopic and magnetic characterization of the bis( $\mu$-hydroxido)diiron(III) compound $\left[\mathrm{Fe}^{\mathrm{III}}{ }_{2}(\mu-\mathrm{OH})_{2}(\mathbf{b i k})_{4}\right]\left(\mathrm{NO}_{3}\right)_{4}(\mathbf{1})$ and the mononuclear compound $\left[\mathrm{Fe}^{\mathrm{II}}(\mathbf{b i k})_{3}\right]$ $(\mathrm{OTf})_{2}(\mathbf{2})$. In addition, compound $\mathbf{1}$ was studied with density functional theory (DFT). 
Compound 2 was found to be active in the oxidation of alkanes and alkenes with either $t$ $\mathrm{BuOOH}$ or $\mathrm{H}_{2} \mathrm{O}_{2}$ as the oxidant.

\section{Experimental Section}

Air-sensitive reactions were carried out under an atmosphere of dry, oxygen-free $\mathrm{N}_{2}$ using standard Schlenk techniques. All chemicals were commercially obtained and used as received. THF was dried over sodium benzophenone ketyl and distilled under $\mathrm{N}_{2}$ prior to use. Methanol was dried over magnesium methoxide and distilled under $\mathrm{N}_{2}$ prior to use. Bis(1-methylimidazol-2-yl)ketone (bik) ${ }^{26}$ and $\mathrm{Fe}(\mathrm{OTf})_{2} \cdot 2 \mathrm{MeCN}^{27}$ were prepared according to literature procedures. All other chemicals were commercially obtained and used as received. ${ }^{1} \mathrm{H}$ and ${ }^{13} \mathrm{C}\left\{{ }^{1} \mathrm{H}\right\}$ NMR spectra were recorded on a Varian AS400 or Varian Inova 300 spectrometer, operating at $25^{\circ} \mathrm{C}$. Elemental microanalyses were carried out by the Microanalytisches Laboratorium Dornis \& Kolbe, Mülheim a.d. Ruhr, Germany. Infrared spectra were recorded on a Perkin Elmer Spectrum One FT-IR instrument. ESI-MS spectra were recorded on a Micromass LC-TOF mass spectrometer by the Biomolecular Mass Spectrometry group, Utrecht University. Solution magnetic moments were determined by Evans' NMR method in acetone $d_{6} /$ cyclohexane $(95 / 5 \mathrm{v} / \mathrm{v})$ at a temperature range of -25 to $50{ }^{\circ} \mathrm{C}$. UV-Vis spectra were recorded on a Varian Cary 50 spectrometer equipped with a Helma immersion probe for in situ measurements.

Bulk magnetization measurements on crushed polycrystalline samples were performed with a Quantum Design MPMS-5 5T (1, 2-300 K) or MPMS-XL (2, 6-400 K) SQUID magnetometer. Data were corrected for magnetization of the sample holder in the case $\mathbf{1}$, but not 2, since its contribution in the latter case was found to be negligible. Diamagnetic contributions were estimated from Pascal's constants. TGA measurements were performed using a Setaram TAG 24 thermoanalyzer.

Mössbauer spectra were recorded with two spectrometers operating in constant acceleration mode. High-field spectra (8 T) were obtained using Janis Research Super-Varitemp Dewar equipment with a superconducting magnet. Isomeric shifts are quoted relative to the $\mathrm{Fe}$ metal at $298 \mathrm{~K}$. Mössbauer spectral simulations were calculated using the WMOSS software package (WEB Research, Edina, MN). The calculations were performed with Gaussian 03 (revision E.01), using the functional/basis set B3LYP/6-311G. Density functional calculations were carried out on models for the bare tetracationic complex $\left[\mathrm{Fe}_{2}(\mu-\right.$ $\left.\mathrm{OH})_{2}(\mathbf{b i k})_{4}\right]^{4+}\left(\left\{\mathbf{1}_{\text {bare }}\right\}\right)$ and the dicationic complex $\left\{\left[\mathrm{Fe}_{2}(\mu-\mathrm{OH})_{2}(\mathbf{b i k})_{4}\right]\left(\mathrm{NO}_{3}\right)_{2}\right\}^{2+}$

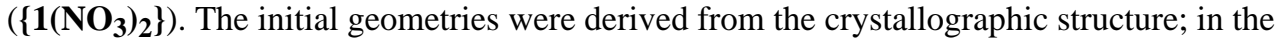
case of $\left\{\mathbf{1}\left(\mathbf{N O}_{\mathbf{3}}\right)_{\mathbf{2}}\right\}$ the optimization was started from the geometry of $\left\{\mathbf{1}_{\text {bare }}\right\}$ appended with two nitrates at the hydroxide bridges. The geometry optimizations were carried out on

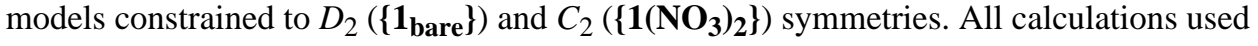
tight SCF convergence criteria. Relaxed geometry scans were performed keeping the respective $D_{2} / C_{2}$ symmetries, using the $\mathrm{Fe} \cdots \mathrm{Fe}$ distance as the scanning parameter, and optimizing the remaining internal coordinates. The exchange-coupling constant was calculated with the broken-symmetry (BS) method, using the expression $J=[E(\mathrm{~F})-E(\mathrm{BS})] /$ 12.5 (convention: $\mathscr{H}=J \mathbf{S}_{1} \cdot \mathbf{S}_{2}$ ) where $E(\mathrm{~F})$ and $E(\mathrm{BS})$ are the total self-consistent field energies of the ferromagnetic (F) and BS states, respectively.

\section{$\left[\mathrm{Fe}_{2}(\mu-\mathrm{OH})_{2}(\mathrm{bik})_{4}\right]\left(\mathrm{NO}_{3}\right)_{4}(1)$}

To a solution of bik $(1.85 \mathrm{~g}, 9.73 \mathrm{mmol})$ in ethanol/water $(32 \mathrm{~mL}, 15: 1 \mathrm{v} / \mathrm{v})$ was added an orange solution of $\mathrm{Fe}\left(\mathrm{NO}_{3}\right)_{3} \cdot 9 \mathrm{H}_{2} \mathrm{O}(1.96 \mathrm{~g}, 4.86 \mathrm{mmol})$ in ethanol $(30 \mathrm{~mL})$. The solution was stirred for $90 \mathrm{~min}$ at $60^{\circ} \mathrm{C}$, during which gradually a yellowish-orange precipitate formed. The precipitate was separated by centrifugation, washed with ethanol $(30 \mathrm{~mL})$ and dried in vacuo. The product was obtained as a yellowish-orange powder $(2.65 \mathrm{~g}, 94 \%$ yield $)$. 
Orange-red crystals of 1 suitable for $\mathrm{X}$-ray diffraction were obtained by slow evaporation of a water solution. Anal. for $\mathrm{C}_{36} \mathrm{H}_{42} \mathrm{Fe}_{2} \mathrm{~N}_{20} \mathrm{O}_{18} \cdot 2 \mathrm{H}_{2} \mathrm{O}$ (1190.56): calc. C 36.32, H 3.89, N 23.53; found C 36.45, H 3.81, N 23.61. IR (solid) $v=3549.2$, 3437.9, 3105.2, 3068.9, 1661.9, 1490.2, 1463.8, 1424.4, 1401.6, 1357.9, 1309.6, 1166.8, 1037.4, 960.5, 900.7, 827.3, 790.4, 773.4, $726.0 \mathrm{~cm}^{-1}$. UV-Vis $\left(\mathrm{MeOH}, \varepsilon\left[\mathrm{M}^{-1} \mathrm{~cm}^{-1}\right]\right): \lambda_{\max }=285$ (43000), 327 (71000) $\mathrm{nm}$.

\section{$\left[\mathrm{Fe}(\mathrm{bik})_{3}\right](\mathrm{OTf})_{2}(2)$}

To a colorless solution of bik $(255 \mathrm{mg}, 1.35 \mathrm{mmol})$ in dry methanol $(15 \mathrm{~mL})$ was added a colorless solution of $\mathrm{Fe}(\mathrm{OTf})_{2} \cdot 2 \mathrm{MeCN}(197 \mathrm{mg}, 0.45 \mathrm{mmol})$ in dry methanol $(5 \mathrm{~mL})$ and immediately a color change to dark purplish blue was observed. The solution was stirred for $30 \mathrm{~min}$ at room temperature, after which diethyl ether $(30 \mathrm{~mL})$ was added to precipitate the product. The precipitate was separated by centrifugation, washed with diethyl ether $(2 \times 20$ $\mathrm{mL}$ ) and dried in vacuo to give a dark blue powder. Recrystallization from methanol/diethyl ether at $-30{ }^{\circ} \mathrm{C}$ yielded the product as a blue microcrystalline powder $(384 \mathrm{mg}, 89 \%)$. Blue crystals suitable for $\mathrm{X}$-ray diffraction were obtained by slow vapor diffusion of diethyl ether into a methanolic solution of 2. Anal. for $\mathrm{C}_{29} \mathrm{H}_{30} \mathrm{~F}_{6} \mathrm{FeN}_{12} \mathrm{O}_{9} \mathrm{~S}_{2}$ (924.59): calc. C 37.67, $\mathrm{H}$ 3.27, N 18.18; found C 37.59, H 3.34, N 18.08. ${ }^{1} \mathrm{H}$ NMR (300 MHz, $\left.\mathrm{CD}_{3} \mathrm{OD}\right) 25^{\circ} \mathrm{C}: \delta=$ $4.18\left(\mathrm{~s}, 2 \mathrm{H}, H_{\mathrm{im}}\right), 7.59$ (s, $\left.6 \mathrm{H}, \mathrm{CH}_{3}\right), 18.05\left(\mathrm{~s}, 2 \mathrm{H}, H_{\mathrm{im}}\right) \mathrm{ppm} ;-95^{\circ} \mathrm{C}: \delta=4.18\left(\mathrm{~s}, 6 \mathrm{H}, \mathrm{CH}_{3}\right)$, $6.34\left(\mathrm{~s}, 2 \mathrm{H}, H_{\mathrm{im}}\right), 7.65$ (s, 2H, $\left.H_{\mathrm{im}}\right) \mathrm{ppm}$. IR (solid) $v=3561.73134 .3,2970.4,1628.6$, $1521.2,1486.8,1420.5,1253.6,1223.0,1144.4,1028.1,896.3,788.3,767.0 \mathrm{~cm}^{-1}$. UV-Vis $\left(\mathrm{MeOH}, \varepsilon\left[\mathrm{M}^{-1} \mathrm{~cm}^{-1}\right]\right): \lambda_{\max }=236(14000), 290(26000), 324(51000), 583(4500) \mathrm{nm}$. ESI-MS: $m / z=313.07\left\{\left[\mathrm{Fe}^{\mathrm{II}}(\text { bik })_{3}\right]^{2+}\right.$, calc. 313.10$\}, 584.97\left\{\left[\mathrm{Fe}^{\mathrm{II}}(\text { bik })_{2}(\mathrm{OTf})\right]^{+}\right.$, calc. $585.06\}, 775.18\left\{\left[\mathrm{Fe}^{\mathrm{II}}(\mathrm{bik})_{3}(\mathrm{OTf})\right]^{+}\right.$, calc. 775.14$\}, 925.15\left\{\left[\mathrm{FeII}(\mathrm{bik})_{3}(\mathrm{OTf})_{2}+\mathrm{H}\right]^{+}\right.$, calc. $925.10\}$.

\section{Catalysis protocol}

To a stirred solution of catalyst $2(3 \mu \mathrm{mol})$ in acetonitrile $(2 \mathrm{~mL})$ was added substrate (1000 eq, $3 \mathrm{mmol}$ ) and acetonitrile (to bring the total volume to $2.5 \mathrm{~mL}$ ). Subsequently, $0.5 \mathrm{~mL}$ of oxidant solution (100 eq, $600 \mathrm{mM}$ solution in acetonitrile diluted from $35 \%$ aqueous $\mathrm{H}_{2} \mathrm{O}_{2}$ or $70 \%$ aqueous $t-\mathrm{BuOOH}$ ) was added either dropwise in $20 \mathrm{~min}$ or at once. The ratio of catalyst:oxidant:substrate was 1:100:1000. The reaction mixture was stirred at room temperature and after 1 hour (from start of oxidant addition) internal standard $(10 \mu \mathrm{L}$, cyclooctene: 1,2-dibromobenzene, cyclohexane: chlorobenzene, all other substrates: bromobenzene) was added and the first sample was taken. After three (alkanes) or seven hours (alkenes) a second sample was taken from the reaction mixture. The aliquots of the reaction mixture were filtered over a short silica plug, after which the short column was flushed twice with diethyl ether. The samples were concentrated by a stream of $\mathrm{N}_{2}$ and analyzed by GC. The products were identified and quantified by GC by comparison with authentic compounds. The reported values are the average of at least two independent runs.

\section{X-ray crystal structure determinations of 1 and $\mathbf{2} \cdot \mathbf{M e O H}$}

Reflections were measured on a Nonius Kappa CCD diffractometer with rotating anode (graphite monochromator, $\lambda=0.71073 \AA$ ) at a temperature of $150 \mathrm{~K}$. Intensities were integrated with EvalCCD ${ }^{28}$ using an accurate description of the experimental setup for the prediction of the reflection contours. The structures were refined with SHELXL-9729 against $\mathrm{F}^{2}$ of all reflections. Non hydrogen atoms were refined with anisotropic displacement parameters. Hydrogen atoms were introduced in geometrically optimized positions. The O$\mathrm{H}$ hydrogen atoms were refined freely with isotropic displacement parameters; all other hydrogen atoms were refined with a riding model. Geometry calculations and checking for higher symmetry was performed with the PLATON program. ${ }^{30}$ 


\section{X-ray crystal structure determination of 1}

$\left[\mathrm{C}_{36} \mathrm{H}_{42} \mathrm{Fe}_{2} \mathrm{~N}_{16} \mathrm{O}_{6}\right]\left(\mathrm{NO}_{3}\right)_{4} \cdot 2 \mathrm{H}_{2} \mathrm{O}, \mathrm{Fw}=1190.63$, colorless block, $0.22 \times 0.13 \times 0.05 \mathrm{~mm}^{3}$, monoclinic, $\mathrm{C} 2 / \mathrm{c}$ (no. 15), $\mathrm{a}=23.5604(10), \mathrm{b}=14.6757(10), \mathrm{c}=13.9671(10) \AA, \beta=$ 92.071(1) $)^{\circ}, \mathrm{V}=4826.2(5) \AA^{3}, \mathrm{Z}=4, \mathrm{D}_{\mathrm{x}}=1.639 \mathrm{~g} / \mathrm{cm}^{3}, \mu=0.70 \mathrm{~mm}^{-1} .88283$ Reflections were measured up to a resolution of $(\sin \theta / \lambda)_{\max }=0.62 \AA^{-1}$. The crystal appeared to be nonmerohedrally twinned with a twofold rotation about the reciprocal $c^{*}$-axis as twin operation. This twin operation was taken into account during the integration of the intensities and the refinement as a HKLF5 refinement. ${ }^{31}$ The reflections were corrected for absorption and scaled on the basis of multiple measured reflections with the program TWINABS ${ }^{32}$ (0.76- 0.96 correction range). 4782 Reflections were unique $\left(\mathrm{R}_{\text {int }}=0.0547\right)$. The structure was solved with the program SHELXS-86 33 using Direct Methods. 369 Parameters were refined with 3 restraints. R1/wR2 [I>2 $\sigma(\mathrm{I})$ ]: 0.0473/0.0934. R1/wR2 [all refl.]: $0.0677 / 0.1029$. $\mathrm{S}=1.081$. The twin fraction refined to $0.1049(16)$. Residual electron density between -0.43 and $0.60 \mathrm{e} / \AA^{3}$.

\section{X-ray crystal structure determination of $2 \cdot \mathrm{MeOH}$}

$\left[\mathrm{C}_{27} \mathrm{H}_{30} \mathrm{FeN}_{12} \mathrm{O}_{3}\right]\left(\mathrm{CF}_{3} \mathrm{O}_{3} \mathrm{~S}\right)_{2} \cdot \mathrm{CH}_{3} \mathrm{OH}, \mathrm{Fw}=956.66$, dark blue plate, $0.24 \times 0.18 \times 0.06$ $\mathrm{mm}^{3}$, orthorhombic, Fdd2 (no. 43), $\mathrm{a}=25.85847(1), \mathrm{b}=50.00278(10), \mathrm{c}=11.81363(2) \AA$, $\mathrm{V}=15274.97(15) \AA^{3}, \mathrm{Z}=16, \mathrm{D}_{\mathrm{x}}=1.664 \mathrm{~g} / \mathrm{cm}^{3}, \mu=0.61 \mathrm{~mm}^{-1} .65769$ Reflections were measured up to a resolution of $(\sin \theta / \lambda)_{\max }=0.65 \AA^{-1}$. The reflections were corrected for absorption and scaled on the basis of multiple measured reflections with the program $\operatorname{SADABS}^{34}\left(0.76-0.96\right.$ correction range). 8742 Reflections were unique $\left(\mathrm{R}_{\mathrm{int}}=0.0418\right)$. The structure was solved with the program SIR-97 ${ }^{35}$ using Direct Methods. One triflate anion was refined with a disorder model. 594 Parameters were refined with 92 restraints. R1/wR2 [I $>2 \sigma(\mathrm{I})$ ]: $0.0278 / 0.0593 . \mathrm{R} 1 / \mathrm{wR} 2$ [all refl.]: 0.0357/0.0624. $\mathrm{S}=1.033$. Flack parameter $\mathrm{x}=$ $0.001(8) .{ }^{36}$ Residual electron density between -0.20 and $0.21 \mathrm{e} / \AA^{3}$.

\section{Results}

\section{Synthesis and structural characterization of a dinuclear bis( $\mu$-hydroxido)diiron(III) complex}

To construct dinuclear iron(III) complexes with the $N, N$-bidentate bis(1-methylimidazol-2yl)ketone (bik) ligand we adopted the synthetic route reported for the $\left[\left((\text { phen })_{2}\left(\mathrm{H}_{2} \mathrm{O}\right) \mathrm{Fe}^{\mathrm{III}}\right)_{2}(\mu-\mathrm{O})\right](\mathrm{X})_{4}$ complexes $\left(\mathrm{X}=\mathrm{NO}_{3}, \mathrm{ClO}_{4}\right) .8,21$ The addition of two equivalents of bik to a solution of $\mathrm{Fe}(\mathrm{III})$ nitrate in ethanol/water resulted in the gradual formation of a yellowish-orange precipitate. Recrystallization of the precipitate from an aqueous solution yielded red-orange crystals. The product was identified as a $C_{2}$ symmetric dinuclear iron complex of the composition $\left[\mathrm{Fe}^{\mathrm{III}}{ }_{2}(\mu-\mathrm{OH})_{2}(\mathbf{b i k})_{4}\right]\left(\mathrm{NO}_{3}\right)_{4} \cdot 2 \mathrm{H}_{2} \mathrm{O}(\mathbf{1})$ by X-ray crystal structure determination, elemental analysis, and IR spectroscopy. Complex $\mathbf{1}$ features an $\mathrm{Fe}_{2}^{\mathrm{III}} 2(\mu-\mathrm{OH})_{2}$ diamond core (vide infra), which is spontaneously formed by selfassembly (i.e. no base was added to the reaction mixture). ${ }^{37}$ Some of the structural features of $\mathbf{1}$ are reflected in its infrared absorption spectrum. The IR spectra of the isolated yelloworange colored powder and the red-orange crystals are identical except for the presence of a broad absorption centered around $3100 \mathrm{~cm}^{-1}$ for the red-orange crystals. This broad absorption can be attributed to the $\mathrm{OH}$ stretching mode of co-crystallized water molecules. The binding of the bik ligand to a Fe(III) metal center results in a strong shift of the carbonyl stretching vibration to higher wave numbers by $32 \mathrm{~cm}^{-1}$ and is now found at 1662 $\mathrm{cm}^{-1}$. Two absorptions of equal intensity are observed at 3438 and $3549 \mathrm{~cm}^{-1}$, of which the latter is tentatively assigned as the $\mathrm{OH}$ stretch vibration of the bridging $\mathrm{OH}$ groups.

It is important to note that reaction of bik with iron(III) nitrate in the presence of water does not lead to the formation of the hydrated bis(1-methylimidazol-2-yl)methanediol ligand. It is well known that the similar bis(2-pyridyl)ketone ligand (bpk) easily hydrates upon 
coordination to several different transition metals, ${ }^{38-41}$ including iron(III). For instance, reaction of $\mathrm{Fe}\left(\mathrm{NO}_{3}\right)_{3} \cdot 9 \mathrm{H}_{2} \mathrm{O}$ with two equivalents of bpk in water leads to the formation of the geminal diol of bpk. Two hydrated ligands then coordinate in a tridentate fashion to the metal center, resulting in a mononuclear bis-ligand complex. ${ }^{42}$ Apparently, the carbonyl carbon atom of bik is less susceptible to nucleophilic attack of water after coordination to a $\mathrm{Fe}(\mathrm{III})$ center.

\section{Crystal Structure of $\left[\mathrm{Fe}^{\mathrm{III}}{ }_{2}(\mu-\mathrm{OH})_{2}(\mathrm{bik})_{4}\right]\left(\mathrm{NO}_{3}\right)_{4} \cdot 2 \mathrm{H}_{2} \mathrm{O}$}

Red-orange crystals of $\mathbf{1}$ suitable for X-ray diffraction were obtained by slow evaporation of an aqueous solution of $\mathbf{1}$. The molecular structure of the dinuclear cation of $\mathbf{1}$ is depicted in Figure 2, with selected bond lengths and angles presented in Table 1.

The crystal structure of the cation of $\mathbf{1}$ consists of a dinuclear unit with two crystallographically equivalent iron(III) metal centers that are bridged by two hydroxide groups. The two equivalent Fe(III) ions are related by a twofold rotation axis parallel to the monoclinic $b$-axis. Two bik ligands are coordinated in a bidentate fashion to each of the iron atoms, resulting in an $\mathrm{N}_{4} \mathrm{O}_{2}$ donor set and a distorted octahedral coordination geometry around the metal center. The $\mathrm{Fe}_{2}(\mu-\mathrm{OH})_{2}$ core is planar, with the Fe1-O3 and $\mathrm{Fe} 1-\mathrm{O} 3$ a bond lengths equal within error (1.941(2) and 1.949(2) $\AA$, resp.). The distance between the metal centers is 3.0723(6) $\AA$ and the $\mathrm{Fe} 1-\mathrm{O} 3-\mathrm{Fe} 1$ (a) bridging angle of the planar unit is $104.32(9)^{\circ}$. Only a limited number of structures with an unsupported ${ }^{43-51}$ or supported $^{52-54}$ $\mathrm{Fe}^{\mathrm{III}}{ }_{2}(\mu-\mathrm{OH})_{2}$ core have been reported. The metal-metal distance in $\mathbf{1}$ is on the short side of the range reported for structures with a doubly bridged, unsupported $\mathrm{Fe}^{\mathrm{III}}{ }_{2}(\mu-\mathrm{OH})_{2}$ core (3.078-3.161 А). ${ }^{43-49}$ The relatively short Fe $\cdots$ Fe distance may be due to the assembly of the core with neutral bik ligands only. All other crystallized complexes were constructed with anionic ligands, which lead to longer $\mathrm{Fe}-\mathrm{OH}$ bond lengths trans to the anionic donor groups and a concomitant increase in intermetallic separation. Consequently, the $\mathrm{Fe}-\mathrm{OH}$ bond lengths in $\mathbf{1}$ are relatively short (1.941(2)/1.949(2) ̊ for Fe1-O3/Fe-O3a). In addition, the hydrogen bonding interactions that are observed between the bridging hydroxide groups and the co-crystallized nitrates might also attribute to more acute $\mathrm{Fe}-\mathrm{O}-\mathrm{Fe}$ angles, thus leading to shorter Fe...Fe distance (vide infra). The diminished transoid (164.75(9)-171.44(10) $\AA$ ) and N-Fe-N angles, the latter caused by the limited 'bite' of the bik ligand, distort the octahedral symmetry.

The $\mathrm{Fe}^{\mathrm{III}}{ }_{2}(\mu-\mathrm{OH})_{2}$ core of the dinuclear cation is stabilized by hydrogen bonds, since the hydroxide group is involved in an intermolecular, bifurcated hydrogen bond $\left(\Sigma_{\text {angles }}=360^{\circ}\right)$ with $\mathrm{O} 7$ and $\mathrm{O} 8$ of a nitrate anion as acceptors (Figure 3 (left), Table 2). This hydrogen bond is asymmetric, as reflected by the different $\mathrm{H} \cdots \mathrm{O}$ bond lengths of $1.82(2) \AA(\mathrm{O} 8)$ and 2.43(3) $\AA$ (O7). The co-crystallized water molecules and the two other nitrate anions are also involved in hydrogen bonding interactions with each other. This leads to the formation of an infinite linear chain in the direction of the crystallographic $b$-axis. Sheets of the infinite linear chains run in between layers of the dinuclear cations, which are also oriented in the direction of the crystallographic $b$-axis (Figure 3 (right), Table 2).

\section{Magnetic properties of 1}

The temperature-dependent magnetic susceptibility of $\mathbf{1}$, measured on polycrystalline material from 2 to $300 \mathrm{~K}$, is shown in Figure 4 in the form of $\chi_{\mathrm{M}} \mathrm{T}$ versus $\mathrm{T}(4 \mathrm{~A})$ and $\chi_{\mathrm{M}}$ versus $\mathrm{T}(4 \mathrm{~B})$ plots. The $\chi_{\mathrm{M}} \mathrm{T}$ product for $\left[\mathrm{Fe}_{2}(\mu-\mathrm{OH})_{2}(\mathbf{b i k})_{4}\right]\left(\mathrm{NO}_{3}\right)_{4} \cdot 2 \mathrm{H}_{2} \mathrm{O}$ at $300 \mathrm{~K}$ is 4.71 $\mathrm{cm}^{3} \mathrm{~mol}^{-1} \mathrm{~K}$, which is significantly lower than the spin-only value for two non-interacting iron(III) ions with $S=5 / 2\left(8.75 \mathrm{~cm}^{3} \mathrm{~mol}^{-1} \mathrm{~K}\right)$. The $\chi_{\mathrm{M}} \mathrm{T}$ value decreases down to $0.012 \mathrm{~cm}^{3}$ $\mathrm{mol}^{-1} \mathrm{~K}$ at $10 \mathrm{~K}$ due to antiferromagnetic coupling of the two iron(III) centers. The 
experimental data were fitted to the expression for the molar susceptibility derived from the Hamiltonian $\mathscr{H}=J \mathbf{S}_{1} \cdot \mathbf{S}_{2}: 55$

$$
\chi_{\mathrm{M}}=\frac{2 \mathrm{~N}_{\mathrm{A}} g^{2} \beta^{2}}{\mathrm{kT}} \cdot \frac{\mathrm{e}^{\mathrm{x}}+5 \mathrm{e}^{3 \mathrm{x}}+14 \mathrm{e}^{6 \mathrm{x}}+30 \mathrm{e}^{10 \mathrm{x}}+55 \mathrm{e}^{15 \mathrm{x}}}{1+3 \mathrm{e}^{\mathrm{x}}+5 \mathrm{e}^{3 \mathrm{x}}+7 \mathrm{e}^{6 \mathrm{x}}+9 \mathrm{e}^{10 \mathrm{x}}+11 \mathrm{e}^{15 \mathrm{x}}}
$$

where $\mathrm{x}=J / \mathrm{kT}$. The best fit to the $\chi_{\mathrm{M}} \mathrm{T}$ versus $\mathrm{T}$ curve gave $g=2$ and the exchange parameter $J=35.9 \mathrm{~cm}^{-1}\left(\mathrm{R}=8.9 \times 10^{-4}\right)$.

The $J$ value is larger than the reported $J$ values for other dinuclear bis( $\mu$-hydroxido)iron(III) compounds $\left(6<J<22 \mathrm{~cm}^{-1}\right) .43,45-48,50,51$ The magnitude of the exchange parameter $J$ has been shown to increase with decreasing $\mathrm{Fe}-\mathrm{O}$ distance (see below) ${ }^{56,57}$ Indeed, 1 has the shortest average $\mathrm{Fe}-\mathrm{O}$ bond length of crystallographically characterized $\left[\mathrm{Fe}^{\mathrm{III}}(\mu-\mathrm{OH})_{2}\right]$ complexes for which $J$ has been reported. Interestingly, the observed $J$ value for $\mathbf{1}$ is rather similar to the exchange parameter that was recently reported for the first crystallographically characterized diiron(III) compound with a single hydroxide bridge $\left(J=41.8 \mathrm{~cm}^{-1}\right) .57$

\section{Mössbauer analysis of 1}

The $4.2 \mathrm{~K}, 0.04 \mathrm{~T}$ Mössbauer spectrum of a polycrystalline sample of $\mathbf{1}$ consists of a quadrupole doublet with isomer shift $\delta=0.45 \mathrm{~mm} / \mathrm{s}$ and quadrupole splitting $\Delta E_{\mathrm{Q}}=0.26$ $\mathrm{mm} / \mathrm{s}$, values that are typical for high-spin iron(III). Attempts to determine $J$ in $\mathbf{1}$ from the temperature dependence of high-field Mössbauer spectra as previously described by some of us, ${ }^{57}$ were hampered by magnetic hyperfine broadening resulting from the electronic relaxation not being entirely fast in the critical temperature range. However, if these relaxational effects on the line position are ignored, matching peak positions are obtained for $J$ values of 30 to $40 \mathrm{~cm}^{-1}$. This range contains the value $J=35.9 \mathrm{~cm}^{-1}$ obtained from the magnetic susceptibility analysis on the polycrystalline material of $\mathbf{1}$ (see above).

\section{DFT analysis of hydrogen bonding effects on the structure and $J$ of 1}

To further explore the influence of the geometrical features and bonding interactions of the $\mathrm{Fe}^{\mathrm{III}}(\mu-\mathrm{OH})_{2}$ core on the electronic structure and resulting magnetic properties of the complex, we have performed DFT calculations on the tetracationic complex, $\left\{\mathbf{1}_{\text {bare }}\right\}$, and the dicationic nitrate-appended compound $\left\{\mathbf{1}\left(\mathbf{N O}_{3}\right)_{2}\right\}$. An overlay of the optimized DFT geometry and the X-ray crystal structure of $\mathbf{1}$ (Figure S1 of the Supporting Information) reveals overall a good agreement between experiment and theory. However, there are also two clear discrepancies: $\mathrm{Fe}-\mathrm{O}=2.02 / 1.941(2)$ and 1.949(2) and $\mathrm{Fe} \cdots \mathrm{Fe}=3.28 / 3.0723(6) \AA$ (DFT/X-ray at $150 \mathrm{~K}$ ). The difference in the $\mathrm{Fe} \cdots \mathrm{Fe}$ separation corresponds to a $6^{\circ}$ difference in the $\mathrm{Fe}-\mathrm{O}-\mathrm{Fe}$ bridge angle. The discrepancy between the calculated and the experimental $\mathrm{Fe}-\mathrm{O}$ distance is rather large compared to the results obtained previously for the singly hydroxide-bridged species $\left[\left\{(\text { salten }) \mathrm{Fe}^{\mathrm{III}}\right\}_{2}(\mathrm{OH})\right]^{+}(3),{ }^{57}$ i.e. $2.03 / 1.9961(5) \AA$ (DFT/X-ray at $293 \mathrm{~K})$. The DFT results for the Fe-O distance in $\mathbf{1}$ and $\mathbf{3}$ (2.02 and $2.03 \AA$ ) are nearly identical, showing that the combined effect of the differences in coordination $\left(\mathrm{N}_{4} \mathrm{O}_{2}\right.$ and $\left.\mathrm{N}_{3} \mathrm{O}_{3}\right)$, overall charge $(+4$ and +1$)$, and number of hydroxide bridges ( 2 and 1$)$ on the $\mathrm{Fe}-\mathrm{O}$ distance is small in these calculations. A plausible explanation for the shorter $\mathrm{Fe}-\mathrm{O}$ distance in the $\mathrm{X}$-ray crystal structure of $\mathbf{1}$ is the presence of hydrogen bonds between the bridging hydroxide groups and the $\mathrm{NO}_{3}{ }^{-}$counter ions (see Figure 3 ). The implied proton sharing may have introduced some oxide character in the hydroxide bridges, leading to shorter Fe-O distances than obtained by DFT calculations for the isolated compound $\left\{\mathbf{1}_{\text {bare }}\right\}$. 
Establishing the dependence of $J$ on molecular structure is one of the main objectives of magneto chemistry. ${ }^{55}$ Gorun and Lippard ${ }^{56}$ presented an empirical relationship between $J$ in diiron(III) complexes with oxide, hydroxide, alkoxide, ... bridges supported by at least one other bridging ligand and the quantity $\mathrm{P}$, which is defined as half the shortest superexchange pathway between the two high-spin $\mathrm{Fe}^{\mathrm{III}}$. In the present convention for $J$ ( $\mathscr{H}=$ $\left.J \mathbf{S}_{1} \cdot \mathbf{S}_{2}\right)$, the relationship is given by the expression $J_{\mathrm{GL}}(\mathrm{P})=1.752610^{12} \exp [-12.663 \mathrm{P}]$ $\mathrm{cm}^{-1}$, with $\mathrm{P}$ ranging from $\sim 1.8 \AA$ (for oxide bridges) to $\sim 2.0 \AA$ (for hydroxide bridges). The value $J_{\mathrm{GL}}=35.7 \mathrm{~cm}^{-1}$ for $\mathrm{P}=\mathrm{Fe}-\mathrm{O}=1.944 \AA$ (Table 1 ) is in remarkably good agreement with experiment $\left(35.9 \mathrm{~cm}^{-1}\right)$. The agreement is, however, rather fortuitous as the $J$ values for the complexes with $\mathrm{P}>1.90 \AA$ are strongly scattered ${ }^{56}$ and exhibit large relative deviations from $J_{\mathrm{GL}}$ (a detailed view of this distance range is presented in Figure $\mathrm{S} 2$ of the Supporting Information). Apparently, factors other than the $\mathrm{Fe}-\mathrm{O}$ distance, such as $\mathrm{Fe}-\mathrm{O}-\mathrm{Fe}$ bond angle, dihedral angles, and composition of the coordination sphere of the irons, may affect $J$.

A broken symmetry DFT analysis of the optimized structure for the isolated compound $\left\{\mathbf{1}_{\text {bare }}\right\}$ yields $J_{\mathrm{DFT}}=46 \mathrm{~cm}^{-1.58} J_{\mathrm{DFT}}$ for $\left\{\mathbf{1}_{\mathrm{bare}}\right\}$ is close to the calculated/experimental values reported for $3\left(J=46 / 42 \mathrm{~cm}^{-1}\right)$, but is about $10 \mathrm{~cm}^{-1}$ larger than the experimental $J$ value obtained for $1\left(35.9 \mathrm{~cm}^{-1}\right)$; this in spite of an $\mathrm{Fe}-\mathrm{O}$ distance that is calculated to be 0.1 $\AA$ longer than observed. Given the good performance of DFT in the calculation of $J$ in $\mathbf{3}$, we were reluctant to simply dismiss the discrepancy between $J_{\mathrm{DFT}}$ and $J_{\exp }$ in the case of $\left\{\mathbf{1}_{\text {bare }}\right\}$ as a methodological shortcoming. Even if DFT were able to accurately predict the relationship between $J$ and structure (which, most likely, it is not), $J$ may still be prone to error due to differences between the optimized DFT structure and the actual X-ray crystal structure. These structural discrepancies may be the result of methodological limitations in the accuracy of the DFT geometry optimization, but can also have physical causes, such as interaction of the complex with the crystalline environment. In this context, the influence of the aforementioned hydrogen bonding interactions of the hydroxide bridges with the cocrystallized nitrate ions need to be investigated. It is of interest to explore $J$ as a function of geometry to determine how differences in the DFT and X-ray crystal structures affect the exchange parameter $J$. In particular, relaxed scans of $J$ have been performed as a function of the non-bonding $\mathrm{Fe} \cdots \mathrm{Fe}$ distance (Figure 5), using the geometry of the bare species $\left\{\mathbf{1}_{\text {bare }}\right\}$ and of the compound $\left.\left\{\mathbf{1}_{(\mathbf{N O}} \mathbf{O}_{3}\right)_{2}\right\}$, in which the bridging hydroxide groups are each hydrogen bonded to a nitrate anion, as structural models. As can be seen in Figure 5, the $J$ vs. $\mathrm{Fe} \cdots \mathrm{Fe}$ plots obtained from the two scans are nearly identical. This implies that the hydrogen bonds have no direct effect on $J$, meaning that the electronic state of the diiron(III) core and associated $J$ are not significantly perturbed by the presence of the hydrogen bonds, provided the structure is kept fixed. ${ }^{59}$ However, the hydrogen bonds affect $J$ indirectly by perturbing the structure of the compound. Figures S3-5 of the Supporting Information show plots of $\mathrm{Fe}-\mathrm{O}-\mathrm{Fe}, \mathrm{Fe}-\mathrm{O}$, and $\mathrm{O}-\mathrm{H}$ vs. $\mathrm{Fe} \cdots \mathrm{Fe}$ obtained from the two scans. The points on these curves for the optimized structures of $\left\{\mathbf{1}_{\mathrm{bare}}\right\}$ and $\left\{\mathbf{1}_{(\mathbf{N O}} \mathbf{O}_{\mathbf{2}}\right\}$ have been indicated in these Figures and show that the values for $\mathrm{Fe} \cdots \mathrm{Fe}, \mathrm{Fe}-\mathrm{O}-\mathrm{Fe}$, and $\mathrm{Fe}-\mathrm{O}$ in the optimized structure for $\left.\left\{\mathbf{1}_{(\mathbf{N O}}\right)_{\mathbf{2}}\right\}$ are in much better agreement with the X-ray structural data than the values for $\left\{\mathbf{1}_{\text {bare }}\right\}$. Table 3 shows the effect of the hydrogen bonds on the structure in quantitative terms. The $\mathrm{Fe} \cdots \mathrm{Fe}$ distance in $\left\{\mathbf{1}_{(\mathbf{N O}} \mathbf{N}_{\mathbf{2}}\right\}$ is virtually identical to the experimental value, while the $\mathrm{Fe}-\mathrm{O}-\mathrm{Fe}$ angle and $\mathrm{Fe}-\mathrm{O}$ distance are much closer to the values in the $\mathrm{X}$-ray crystal structure than those in the optimized structure for $\left\{\mathbf{1}_{\text {bare }}\right\}$. The only exception is the $\mathrm{H}-\mathrm{O}$ distance, which is considerably larger than the value deduced from the electron density plot in both the optimized structures. However, such a mismatch can easily occur as the positions of the hydrogens in crystallographic structures are generally poorly defined. Thus, the major part of the discrepancy between the X-ray crystal structure of $\mathbf{1}$ and the DFT optimized structure of $\left\{\mathbf{1}_{\text {bare }}\right\}$ can be attributed to the hydrogen bonding interactions between the bridging hydroxide groups and the co-crystallized nitrate ions. 
Figure 5 shows that $J$ increases as a function of the $\mathrm{Fe} \cdots \mathrm{Fe}$ distance with a rate, $\mathrm{d} J / \mathrm{d}(\mathrm{FeFe})$, of $78 \mathrm{~cm}^{-1} / \AA$ (corresponding to $\mathrm{d} J / \mathrm{d}(\mathrm{Fe}-\mathrm{O}-\mathrm{Fe})=2.7 \mathrm{~cm}^{-1} /$ degree) in both scans. Thus the compound exhibits the same, intrinsic dependence of $J$ on the structure both in the presence and absence of the hydrogen bonds. As the Fe-Fe distance decreases under the influence of the hydrogen bonds from $3.28 \AA$ in the optimized structure for $\left\{\mathbf{1}_{\text {bare }}\right\}$ to $3.07 \AA$ in the optimized structure for $\left\{\mathbf{1}_{(\mathbf{N O}} \mathbf{N}_{\mathbf{2}}\right\}$, the $J$ value undergoes an attendant decrease from 43.7 $\mathrm{cm}^{-1}$ to $28.4 \mathrm{~cm}^{-1}$ (in spite of a concomitant decrease in $\mathrm{Fe}-\mathrm{O}$ distance from $2.03 \AA$ to 1.97 $\AA$, whose effect on $J$ appears to be superseded by the angular effect). While the structural distortion induced by the hydrogen bonding changes $J$ in the right direction, the resulting $J$ value $28.4 \mathrm{~cm}^{-1}$ comes out even smaller than $J_{\exp }=35.9 \mathrm{~cm}^{-1}$. However, the $\mathrm{Fe}-\mathrm{O}$ distance and $\mathrm{Fe}-\mathrm{O}-\mathrm{Fe}$ angle in the optimized structure for $\left.\left\{\mathbf{1}_{(\mathbf{N O}} \mathbf{O}_{3}\right)_{\mathbf{2}}\right\}$ are slightly larger and smaller, respectively, than in the X-ray crystal structure (Table 3), requiring a decrease in the former and increase in the latter to bridge the gap between calculated and experimental structures. Both these changes affect $J$ by increasing its value, further improving the agreement between theory and experiment.

Hydrogen bonding effects on exchange-coupling constants are not without precedent in the literature. For example, hydrogen bonding has been invoked early on to explain the difference in the $J$ values for oxyhemerythrin and hydroxomethemerythrin. ${ }^{60-62}$ However, it should be noted that the latter two systems differ from 1 in two ways. First, the bridging ligand, an $\mathrm{O}^{2-}$ in hemerythrin and $\mathrm{OH}^{-}$in $\mathbf{1}$, acts as an acceptor (in the hydrogen-bond formation with a terminal hydroperoxide ligand at one of the two $\mathrm{Fe}^{3+}$ sites) in oxyhemerythrin and as a donor in the crystalline form of $\mathbf{1}$. Second, while the decrease in the $J$ value for the hydrogen bonded species (i. e., oxyhemerythrin) may result from the increased hydroxide character (weak $J$ ) induced into the oxide bridge (strong $J$ ) by the formation of the hydrogen bond, the decrease in the value for $J$ induced by the hydrogen bonds in $\left.\left\{\mathbf{1}_{\left(\mathrm{NO}_{3}\right.}^{-}\right)_{2}\right\}$ (angular effect) is accompanied by an increase in oxide character.

\section{Formation of an $\left[\mathrm{Fe}^{\mathrm{Il}}(\mathrm{bik})_{3}\right]^{2+}$ complex}

Although compound 1 could be synthesized from ethanol/water and was stable enough to be crystallized from aqueous solution, it was found to be rather unstable in methanol. Yelloworange solutions of $\mathbf{1}$ in methanol slowly turned dark blue in time under ambient conditions (Figure 6).

The color change was monitored by UV-Vis absorption spectroscopy and a new band emerged at $583 \mathrm{~nm}$. The blue chromophore was identified as the $\left[\mathrm{Fe}^{\mathrm{II}}(\mathbf{b i k})_{3}\right]^{2+}$ cation, by comparison with the UV-Vis and IR data of independently synthesized $\left[\mathrm{Fe}^{\mathrm{II}}(\mathbf{b i k})_{3}\right](\mathrm{OTf})_{2}$ (2) (vide infra). ESI-MS measurements on the blue solution showed three prominent ions, corresponding to the $\left\{\mathrm{Fe}^{\mathrm{II}}(\mathbf{b i k})_{3}\right\}^{2+}(\mathrm{m} / z 313.18),\left\{\mathrm{Fe}^{\mathrm{II}}(\mathbf{b i k})_{2} \mathrm{NO}_{3}\right\}^{+}(m / z, 498.21)$ and $\left\{\mathrm{Fe}^{\mathrm{II}}(\text { bik })_{3} \mathrm{NO}_{3}\right\}^{+}(\mathrm{m} / z, 688.34)$ cations.

The Fe(III) centers in $\mathbf{1}$ were therefore in situ reduced to give an air-stable, tris-chelated $\mathrm{Fe}(\mathrm{II})$ compound. The formation of $\left[\mathrm{Fe}^{\mathrm{II}}(\mathbf{b i k})_{3}\right]^{2+}$ has been observed before with ligand systems based on the related bis(1-methylimidazol-2-yl)methane backbone. ${ }^{63-65}$ It should be noted that in these previously reported examples the starting ligand itself is oxidized to bik. Indeed, $\left[\mathrm{Fe}^{\mathrm{II}}(\mathbf{b i k})_{3}\right]^{2+}$ has been identified in the iron-catalyzed oxidations of the ligands bis(1-methylimidazol-2-yl)methanol, ${ }^{64}$ bis(1-methylimidazol-2-yl)-2-methylthioethanol, ${ }^{63}$ and bis(1-methylimidazol-2-yl)methane ${ }^{65}$ to give bik. The nature of the reducing agent in case of the spontaneous reduction of $\left[\mathrm{Fe}^{\mathrm{III}} 2(\mu-\mathrm{OH})_{2}(\mathbf{b i k})_{4}\right]\left(\mathrm{NO}_{3}\right)_{4}(\mathbf{1})$ to $\left[\mathrm{Fe}^{\mathrm{II}}(\mathbf{b i k})_{3}\right]^{2+}$ could so far not be established.

We also observed the formation of the $\left[\mathrm{Fe}^{\mathrm{II}}(\mathbf{b i k})_{3}\right]$ cation in an attempt to synthesize the analogous $\mathrm{Fe}(\mathrm{II})$ complex of $\left[\mathrm{Fe}^{\mathrm{III}}{ }_{2}(\mu-\mathrm{OH})_{2}(\mathbf{b i k})_{4}\right]\left(\mathrm{NO}_{3}\right)_{4}(\mathbf{1})$, i.e. a complex with an 
$\mathrm{Fe}^{\mathrm{II}}{ }_{2}(\mu-\mathrm{OH})_{2}$ core. Following published procedures for the construction of such a structural motif,, $66-68$ equimolar amounts of $\mathrm{Fe}(\mathrm{OTf})_{2} \cdot 2 \mathrm{MeCN}$ and sodium hydroxide were reacted with 2 equiv. of bik in methanol. Immediately upon mixing of the reagents the solution turned dark blue. The blue product was isolated and identified as $\left[\mathrm{Fe}^{\mathrm{II}}(\mathbf{b i k})_{3}\right](\mathrm{OTf})_{2}(\mathbf{2})$ by $\mathrm{X}$-ray diffraction (vide infra). The formation of the $\left[\mathrm{Fe}^{\mathrm{II}}(\mathbf{b i k})_{3}\right]^{2+}$ cation, therefore, seems to be inevitable and can be regarded as a thermodynamic sink in the coordination chemistry of iron and bik. For that reason, our further studies on the structure and reactivity of bik complexes of iron were focused on the $\mathrm{Fe}(\mathrm{II})$ compound $\left[\mathrm{Fe}^{\mathrm{II}}(\mathbf{b i k})_{3}\right](\mathrm{OTf})_{2}(\mathbf{2})$.

\section{Synthesis and characterization of [Fe" $\left.(\text { bik })_{3}\right](\mathrm{OTf})_{2}(2)$}

$\left[\mathrm{Fe}^{\mathrm{II}}(\mathbf{b i k})_{3}\right](\mathrm{OTf})_{2}(\mathbf{2})$ was synthesized by the simple addition of 3 eq of bik to a solution of $\mathrm{Fe}(\mathrm{OTf})_{2} \cdot 2 \mathrm{MeCN}$ in methanol. Recrystallization from methanol/diethyl ether at $-30{ }^{\circ} \mathrm{C}$ yielded $\mathbf{2}$ as a dark blue microcrystalline powder. $\left[\mathrm{Fe}^{\mathrm{II}}(\mathbf{b i k})_{3}\right](\mathrm{OTf})_{2}(\mathbf{2})$ is stable under ambient conditions. In contrast to the observed shift of the carbonyl stretch vibration in the IR spectrum upon coordination of bik to a Fe(III) center (as in 1), no shift is observed for $\left[\mathrm{Fe}^{\mathrm{II}}(\mathbf{b i k})_{3}\right](\mathrm{OTf})_{2}(\mathbf{2})$. The carbonyl stretch vibration is found at $1629 \mathrm{~cm}^{-1}$, identical to that in the free ligand. Four sharp vibrations at $1254,1223,1144$, and $1028 \mathrm{~cm}^{-1}$ are observed for the triflate anions, indicative of the presence of non-coordinated triflate anions. ${ }^{69,70}$ In the ESI-MS spectrum of an acetonitrile solution of $\mathbf{2}$, next to the $\left\{\mathrm{Fe}^{\mathrm{II}}(\mathbf{b i k})_{3}(\mathrm{OTf})_{2}+\mathrm{H}\right\}^{+}$molecular ion $\left(\mathrm{m} / z\right.$ 925.14) the $\left\{\mathrm{Fe}^{\mathrm{II}}(\mathbf{b i k})_{3}(\mathrm{OTf})\right\}^{+}$cation $(\mathrm{m} / \mathrm{z}$ 775.18) and $\left\{\mathrm{Fe}^{\mathrm{II}}(\mathbf{b i k})_{3}\right\}^{2+}$ dication $(\mathrm{m} / z 313.07)$, a prominent ion is observed that corresponds to the $\left\{\mathrm{Fe}^{\mathrm{II}}(\mathbf{b i k})_{2}(\mathrm{OTf})\right\}^{+}$cation $(\mathrm{m} / \mathrm{z}$ 584.97). This shows that ligand dissociation from the $\mathrm{Fe}$ (II) center is rather facile in acetonitrile. Ligand dissociation from the coordinatively saturated complex should lead to two cis-positioned vacant sites at the metal center. This made the readily accessible and easily synthesized $\mathbf{2}$ an attractive candidate for exploring its potential in oxidation catalysis.

\section{Crystal structure and spectroscopic properties of $\left[\mathrm{Fe}^{\prime \prime}(\mathrm{bik})_{3}\right](\mathrm{OTf})_{2} \cdot \mathrm{MeOH}(2 \cdot \mathrm{MeOH})$}

Blue crystals of $\mathbf{2} \cdot \mathbf{M e O H}$ suitable for X-ray diffraction were obtained by slow vapor diffusion of diethyl ether into a solution of $\mathbf{2}$ in methanol. The crystal structure of the cation of $\mathbf{2} \cdot \mathbf{M e O H}$ is depicted in Figure 7 with selected bond lengths and angles in Table 4. The iron(II) metal center in $\mathbf{2} \cdot \mathbf{M e O H}$ is coordinated by three $N, N$-chelate bonded bik ligands, resulting in a slightly distorted octahedral coordination geometry. The $\mathrm{Fe}-\mathrm{N}$ distances range from $1.9942(16)$ to 1.9735 (16) $\AA$ and are characteristic of a low-spin iron(II) metal center ( $S$ $=0$ ). The co-crystallized methanol solvent molecule is hydrogen bonded to one of the triflate anions. Although the complex is inherently chiral, the crystal overall is racemic.

Two other crystal structures with the same $\left[\mathrm{Fe}^{\mathrm{II}}(\mathbf{b i k})_{3}\right]^{2+}$ cation have been reported recently. ${ }^{63,71}$ Remarkably, the crystal structure of $\left[\mathrm{Fe}^{\mathrm{II}}(\mathbf{b i k})_{3}\right]\left(\mathrm{ClO}_{4}\right)_{2}{ }^{63}$ reveals a high-spin iron(II) compound with an average $\mathrm{Fe}-\mathrm{N}$ distance of $2.14 \AA$, whereas in $\left[\mathrm{Fe}^{\mathrm{II}}(\mathbf{b i k})_{3}\right] \mathrm{Cl}_{2}{ }^{71} \mathrm{a}$ low spin $\mathrm{Fe}(\mathrm{II})$ is found with an average $\mathrm{Fe}-\mathrm{N}$ distance of $1.98 \AA$ comparable to the $\mathrm{Fe}-\mathrm{N}$ bond lengths found for $\mathbf{2} \cdot \mathbf{M e O H}$. Since the structure of $\left[\mathrm{Fe}^{\mathrm{II}}(\mathbf{b i k})_{3}\right]\left(\mathrm{ClO}_{4}\right)_{2}$ was determined at $298 \mathrm{~K}$ and the structures of $\left[\mathrm{FeII}(\mathbf{b i k})_{3}\right] \mathrm{Cl}_{2}$ and $\mathbf{2} \cdot \mathbf{M e O H}$ at around $150 \mathrm{~K}$, these differences in bond length suggest the presence of a temperature-induced spin-state conversion.

Spin-crossover is not uncommon for iron(II)- $\mathrm{d}^{6}$ metal complexes with an $\mathrm{N}_{6}{\text { donor } \text { set }^{72} \text { and }}$ spin-crossover has been reported for $\left[\mathrm{Fe}^{\mathrm{II}}(\mathbf{b i k})_{3}\right]\left(\mathrm{BF}_{4}\right)_{2} \cdot{ }^{73}$ The paramagnetism of $\left[\mathrm{Fe}^{\mathrm{II}}(\mathbf{b i k})_{3}\right](\mathrm{OTf})_{2}(\mathbf{2})$ at room temperature and the spin-state change to a diamagnetic lowspin species is also readily apparent in solution from the variable temperature ${ }^{1} \mathrm{H}$ NMR spectra of 2 (Figure 8). At $298 \mathrm{~K}$ the three signals of the imidazole ring are observed at chemical shifts of $4.18\left(H_{\mathrm{im}}\right), 7.58\left(\mathrm{NCH}_{3}\right)$ and $18.04\left(H_{\mathrm{im}}\right) \mathrm{ppm}$, the chemical shifts and 
broadening also being indicative of a solution consisting of a mixture of both high and low spin species in fast exchange. The signals gradually shift to the diamagnetic region upon cooling the sample and are found close to the values of the free ligand at $193 \mathrm{~K}$. Heating of the sample results in an increased population of the high spin state and subsequent further paramagnetic shifting of the signals. At $333 \mathrm{~K}$ for instance, the imidazole proton signal at the highest frequency is found at $27.49 \mathrm{ppm}$.

This interpretation is further substantiated by the change of solution magnetic moments of 2 determined at various temperatures by Evans' NMR method (Figure 8, insert). ${ }^{74,75}$ At room temperature $(298 \mathrm{~K})$ the solution magnetic moment amounts to $3.3 \mu_{\mathrm{B}}$, which corresponds to a mixture of high-spin and low-spin iron(II) configurations. Upon heating the sample to 323 $\mathrm{K}$ the magnetic moment increased to $3.9 \mu_{\mathrm{B}}$. A gradual decrease of the solution magnetic moment to $2.4 \mu_{\mathrm{B}}$ at $268 \mathrm{~K}$ was observed upon cooling. This method did not allow the determination of the magnetic moment at temperatures lower than $268 \mathrm{~K}$, since coalescence of the two probe signals was observed below this temperature. The magnetic properties of solid 2.MeOH were further studied by a variable temperature magnetic susceptibility determination (vide infra).

The visible region of the absorption spectra of $\left[\mathrm{Fe}^{\mathrm{II}}(\mathbf{b i k})_{3}\right](\mathrm{OTf})_{2}(\mathbf{2})$ is dominated by an absorption around $590 \mathrm{~nm}$ at room temperature, causing the blue color of the compound. Upon cooling of a solution of $\mathbf{2}$ in methanol the absorption band increases in intensity $\left(\varepsilon_{298 \mathrm{~K}}\right.$ $\left.4500, \varepsilon_{203 \mathrm{~K}} 7500 \mathrm{M}^{-1} \mathrm{~cm}^{-1}\right)$ and is slightly red shifted $\left(\lambda_{298 \mathrm{~K}} 583, \lambda_{203 \mathrm{~K}} 592 \mathrm{~nm}\right)$. This intensification upon cooling illustrates that the blue color is associated with an electronic transition of the low-spin species.

\section{Magnetic properties of 2}

The thermal variation in the magnetic susceptibility measured for compound $\left[\mathrm{Fe}^{\mathrm{II}}(\mathbf{b i k})_{3}\right]$ $(\mathrm{OTf})_{2} \cdot \mathrm{MeOH}(\mathbf{2} \cdot \mathbf{M e O H})$ under an applied magnetic field of $1 \mathrm{kG}$ in the temperature range of 6 to $400 \mathrm{~K}$ is shown in Figure 9A. In the first heating run, the compound shows a diamagnetic response to the magnetic field from 0 to $200 \mathrm{~K}$ (Figure $9 \mathrm{~A},{ }^{\circ}$ ) until it reaches temperatures around $250 \mathrm{~K}$ where the $\chi_{\mathrm{M}} \mathrm{T}$ value gradually increases. At $400 \mathrm{~K} \chi_{\mathrm{M}} \mathrm{T}=2.79$ $\mathrm{cm}^{3} \mathrm{~mol}^{-1} \mathrm{~K}$, indicating that a fraction of the metal centers are still in the low-spin state and that the transition is thus not complete ( $\mathrm{Fe}^{\mathrm{II}}(\mathrm{HS}), S=2, \chi_{\mathrm{M}} \mathrm{T} \approx 3 \mathrm{~cm}^{3} \mathrm{~mol}^{-1} \mathrm{~K}$ ). In the subsequent cooling run (Figure 9A, $\circ$ ) the system reverts to the diamagnetic $(S=0)$ state, thereby following a different path than in the heating run (hysteresis). However, the hysteresis vanishes in subsequent temperature runs (Figure 9A, $\Delta$ ). Thus, the material shows an irreversible change during the first heating, possibly due to solvent loss.

To verify this possibility, a thermogravimetric analysis (TGA) was performed in the temperature range of 293 to $573 \mathrm{~K}$. Indeed, the compound loses $3.2 \%$ of its total mass between 303 and $373 \mathrm{~K}$ and then stays stable until a temperature of $523 \mathrm{~K}$, above which a second decrease is observed (data not shown). The latter decrease is probably due to decomposition of the compound. As noted previously, compound 2-MeOH crystallizes in the presence of methanol lattice solvent molecules. Their presence corresponds to $3.4 \%$ of the total mass, which nicely matches to the observed weight loss upon heating. That the loss of solvent in the aforementioned temperature range is responsible for the change in the magnetic response is further confirmed by measuring the magnetic susceptibility of $2 \cdot \mathrm{MeOH}$ on cooling it first from room temperature to $6 \mathrm{~K}$ and then heating it back again. As shown in Figure 9B, 2. MeOH traces now the same path in both the cooling and the heating modes.

The effect of solvent molecules on spin crossover has attracted much attention. ${ }^{76-78}$ Hydrogen bonding has been considered as one of the causes for solvent effects. In $\mathbf{2} \cdot \mathbf{M e O H}$, 
the co-crystallized methanol is hydrogen bonded to a triflate anion and also, albeit more weakly, to the methyl group of an imidazole. The observed solvent effect could therefore be due to the hydrogen bonding. Alternately, the changes in the $\chi_{M} T$ vs. $T$ curve may also arise from a structural rearrangement of the compound accompanying the solvent loss. In any case, the spin crossover behavior is only mildly affected by the solvent loss. The concomitant shift in transition temperature is about $25 \mathrm{~K}\left(\mathrm{~T}_{1 / 2}\right.$, solvent $>\mathrm{T}_{1 / 2}$, no solvent $)$.

\section{Oxidation catalysis}

The instability of $\mathbf{1}$ in solution and its subsequent transformation into $\mathbf{2}$, prompted us to study the latter rather than the former compound as a potential oxidation catalyst. The facile dissociation of (at least) one bik ligand from the metal center in acetonitrile, as evidenced by the ESI-MS measurements, results in the availability of two vacant sites at the metal center and would render the coordinatively saturated non-heme iron(II) compound $\mathbf{2}$ a suitable precatalyst for mediating oxidation reactions. The catalytic activity of $\mathbf{2}$ in the oxidation of alkanes and alkenes was tested with $\mathrm{H}_{2} \mathrm{O}_{2}$ and $t$ - $\mathrm{BuOOH}$ as the terminal oxidants.

Alkane functionalization experiments were typically carried out in acetonitrile at room temperature. The oxidant was added dropwise to the reaction mixture with a final 1:100:1000 ratio of 2:oxidant:substrate. Samples were taken three hours after the start of the addition of oxidant. No significant amounts of product were observed in the oxidation of alkanes with hydrogen peroxide as oxidant. The use of tert-butylhydrogen peroxide, however, did result in product formation in reactions of $\mathbf{2}$ with adamantane, cyclohexane and ethylbenzene. The product distribution for the oxidation of adamantane under various conditions is given in Table 5.

Compound 2 oxidizes adamantane with up to $26 \%$ efficiency based on the oxidant. A high $3 \% 2^{\circ}$ value of 19.9 is observed under standard conditions (acetonitrile, air). This value further increases when the reaction is carried out under $\mathrm{N}_{2}$ atmosphere (22.5) or when acetone is used as the solvent (29.6). Adamantane is commonly employed as a mechanistic probe for alkane oxidation and a high selectivity for oxidation at the tertiary position, i.e. a high $3{ }^{\circ} 2^{\circ}$ value, is indicative for involvement of a more discriminating oxidant than freely diffusing hydroxyl or tert-butoxyl radicals. ${ }^{79}$ The latter would result in a $3^{\circ} / 2^{\circ}$ value of up to around $10 .{ }^{79}$ Reported regioselectivities of adamantane oxidation for different non-heme iron/t-BuOOH systems ${ }^{19,80-85}$ vary from 2.7 to 15.4 , with the Gif-type systems on the lower end of the scale ${ }^{80}$ and values of 12.6 and 15.4, for instance, reported for $\left[\mathrm{Fe}\left(\mathrm{Py}(\mathrm{ProMe})_{2}(\mathrm{OTf})_{2}\right]^{81} \text { (Py(ProMe }\right)_{2}, 2,6$-bis $[[(S)-2-($ methyloxycarbonyl)-1pyrrolidinyl]methyl]pyridine) and $\left[\mathrm{Fe}_{2} \mathrm{OL}_{2}\left(\mathrm{NO}_{3}\right)_{2}(\mathrm{MeOH})_{2}\right]^{85}(\mathrm{~L}, 2,6-$ bis $(N-$ methylbenzimidazol-2-yl)pyridine), respectively. The $3^{\circ} / 2^{\circ}$ values observed for 2 seem amongst the highest reported for a non-heme iron/t-BuOOH system and thus suggest the involvement of an active oxidant more selective than free alkyloxy radicals.

Under standard reaction conditions, cyclohexane was converted with $27 \%$ efficiency to cyclohexanol and cyclohexanone with an alcohol to ketone ratio $(\mathrm{A} / \mathrm{K})$ of 0.6. A sharp drop in conversion to around $10 \%$ is observed when the reaction is carried out either in acetone, a known scavenger of oxygen-centered radicals, or under an $\mathrm{N}_{2}$ atmosphere. Similar observations were made for ethylbenzene. The catalytic oxidation of ethylbenzene yielded both acetophenone and 1-phenylethanol with high turnovers and 79\% conversion of the oxidant. Acetophenone was the major product $(\mathrm{A} / \mathrm{K}=0.4)$. Performing the reaction under a nitrogen atmosphere again had a dramatic effect. Conversion dropped to less than $2 \%$ and almost no acetophenone or 1-phenylethanol was formed. Finally, the oxidation of the probe substrate cis-1,2-dimethylcyclohexane proceeded only to a limited extent. Both cis- and trans-1,2-dimethylcyclohexanol were formed and many side products, such as secondary alcohols and ketones were detected as well. The stereoselectivity of the reaction was very 
limited with only $27 \%$ retention of configuration. Data on these catalytic oxidations is reported in Table 6.

Despite the promisingly high $3^{\circ} / 2^{\circ}$ values obtained in the oxidation of adamantane, the results obtained in the oxidation of cyclohexane, ethylbenzene and cis-1,2-

dimethylcyclohexane point to the operation of a free radical-based rather than a metal-based oxidation mechanism under the conditions described here. The low $\mathrm{A} / \mathrm{K}$ value, the (strong) dioxygen dependence, and the low retention of configuration all point to the formation of long-lived free radicals. ${ }^{86,87}$ Alkyloxy radicals could be the result of homolytic cleavage of a tentative iron(III)-tert-butylperoxide species, as has been evidenced in a few cases. ${ }^{81,88}$ The rather powerful tert-butoxy radical then abstracts a hydrogen atom from the alkane to give a long-lived alkyl radical. The free alkyl radicals combine with dioxygen and yield the products in Russell-type termination steps. Although the alkane oxidations of $2 / t-\mathrm{BuOOH}$ seem to be dominated by free radical chemistry, the high $3^{\circ} / 2^{\circ}$ value of 29.6 in the oxidation of adamantane in acetone suggest that other chemically competent oxidants are present in solution as well. The possibility of other mechanisms with different oxidizing species, e.g. metal-based hydrogen abstraction with the formed radicals diffusing into solution, can therefore not be excluded.

The reactivity of $\mathbf{2} / \mathrm{H}_{2} \mathrm{O}_{2}$ towards several different alkenes was also investigated. The alkene oxidation reactions were studied under similar experimental conditions as used for the alkane oxidations (acetonitrile, 2: $\mathrm{H}_{2} \mathrm{O}_{2}$ :substrate, 1:100:1000). The $2 / \mathrm{H}_{2} \mathrm{O}_{2}$ combination was found to be active in olefin oxidation with conversions up to $17 \%$ and the results are listed in Table 7.

While the alkane oxidations reactions were completed after three hours, the olefin oxidations required longer reaction times. Monitoring the reaction in time showed an increase in product formation up to seven hours after the start of the dropwise addition of oxidant. The slow consumption of oxidant suggested that the slow, dropwise addition of oxidation was unnecessary under these conditions. Indeed, when all oxidant was added at once, similar results were obtained. The slow, dropwise addition is usually employed to minimize hydrogen peroxide disproportionation (catalase side reaction). Here, this non-productive consumption of $\mathrm{H}_{2} \mathrm{O}_{2}$ apparently proceeds at a comparably slow rate. Cyclooctene as substrate afforded the epoxide as the sole product with up to $15 \%$ conversion of the oxidant.

We tested the influence of acetic acid as an additive in the oxidation of cyclooctene by $\mathbf{2} /$ $\mathrm{H}_{2} \mathrm{O}_{2}$ (Table 8), since it has been reported to result in an increase in catalytic activity ${ }^{89}$ or change in product selectivity. ${ }^{90}$ In this case, the addition of 30 or 100 eq of acetic acid had a detrimental effect on the catalytic activity, which dropped to $4 \%$ with 100 eq of additive.

Styrene was epoxidized with an efficiency of about $15 \%$, with concomitant formation of some benzaldehyde. 1-Octene and cyclohexene proved to be poorer substrates for the combination $2 / \mathrm{H}_{2} \mathrm{O}_{2}$ with only $7 \%$ and $3 \%$ conversions, respectively, and predominant formation of allylic oxidation products for the latter substrate. The stereoselectivity of the oxidations was studied by the oxidation of the isomeric cis- and trans-2-heptenes. The epoxidation of trans-2-heptene occurs with high stereoselectivity, i.e. $94 \%$ retention of configuration (RC). The stereoretention in the oxidation of cis-2-heptene is somewhat lower ( $\mathrm{RC}=77 \%$ ), which means that some isomerization of an oxidized intermediate to the more stable trans isomer happens prior to epoxide ring formation. The observed stereoselectivity suggests the involvement of a metal-based oxidant and the formation of a substrate radical type intermediate. ${ }^{91}$ This substrate radical species would allow the partial isomerization observed for cis-2-heptene before epoxide ring formation and would account for the observed benzaldehyde formation in the styrene oxidation. ${ }^{92}$ 
The olefin oxidations described above were all conducted with excess substrate with respect to the oxidant. From a practical point of view, however, it is desirable to develop a system capable of doing the oxidations under limiting substrate conditions. Jacobsen et al., for instance, reported the selective olefin epoxidation by a non-heme iron complex using $1.5 \mathrm{eq}$ of $\mathrm{H}_{2} \mathrm{O}_{2}$ with respect to the substrate. ${ }^{89}$ Que et al obtained both epoxide and diol products under limiting substrate conditions with 4 eq of $\mathrm{H}_{2} \mathrm{O}_{2} \cdot{ }^{93}$ To investigate if $\mathbf{2}$ could also mediate olefin oxidation under limiting substrate conditions, different substrate to oxidant ratios were tested (Table 8 ). The results were found to vary significantly and maximum conversion of about $23 \%$ of the substrate to cyclooctene oxide was found using two equivalents of hydrogen peroxide with respect to the substrate. The use of both more or less than two equivalents resulted in a decrease in observed turnover. Two equivalents of hydrogen peroxide is the apparent optimum for the two competing pathways, i.e. substrate oxidation versus catalase activity.

\section{Conclusions}

The study of the iron coordination chemistry of the simple bik building block resulted in the isolation of a $\mathrm{Fe}(\mathrm{III})$ and a $\mathrm{Fe}(\mathrm{II})$ complex and the structural, magnetic and catalytic properties of these compounds were studied. The self-assembly of the $\left[\mathrm{Fe}^{\mathrm{III}}{ }_{2}(\mu-\mathrm{OH})_{2}\right] 4+$ core of the dinuclear compound $\mathbf{1}$ with bik provides an easy access to this interesting structure. The antiferromagnetic coupling of the metal centers was expected, but the observed $J$ value, determined by independent analysis of magnetic susceptibility data and Mössbauer spectra, is larger than reported for other $\mathrm{Fe}^{\mathrm{III}}{ }_{2}(\mu-\mathrm{OH})_{2}$ species but smaller than for the singly bridged compound $\left[\left\{(\text { salten }) \mathrm{Fe}^{\mathrm{III}}\right\}_{2}(\mathrm{OH})\right]^{+}$. DFT calculations show that hydrogen bonding interactions of the bridging hydroxide groups with the co-crystallized nitrates in 1 reduces the $\mathrm{Fe}-\mathrm{OH}$ distance by $0.07 \AA$ and the $\mathrm{Fe}-\mathrm{O}-\mathrm{Fe}$ angle by $4.5^{\circ}$, leading to a $35 \%$ reduction in the value for $J .1$ is actually the first example of a system where the exchange coupling constant is controlled by hydrogen bonding with hydroxido superexchange bridges as the donors. The instability of $\mathbf{1}$ in solution did not allow the study of $\mathbf{1}$ as a potential oxidation catalyst. The decomposition product of $\mathbf{1}$ was identified as $\left[\mathrm{Fe}^{\mathrm{II}}(\mathbf{b i k})_{3}\right]^{2+}$. [FeII $\left.(\mathbf{b i k})_{3}\right](\mathrm{OTf})_{2}(\mathbf{2})$ was independently synthesized and showed spincrossover behavior at $\mathrm{T} \sim 350 \mathrm{~K}$ and was active in the oxidation of alkanes and alkenes. The fact that $\mathbf{2}$ is an air-stable Fe(II) compound, which can be easily obtained in one step, renders compound $\mathbf{2}$ a good starting point for the development of efficient catalysts for the oxidation of alkanes and alkenes by chemical modification.

\section{Supplementary Material}

Refer to Web version on PubMed Central for supplementary material.

\section{Acknowledgments}

This work was financially supported by the National Research School Combination-Catalysis (P.C.A.B.), the Council for Chemical Sciences of the Netherlands Organization for Scientific Research (CW-NWO) (M.L., A.LS.), and the National Institutes of Health Grant EB-001475 (E.M.). Dr. Stefania Tanase-Grecea is kindly acknowledged for her help with the collection of the magnetic measurements. Part of the work was financially supported the ECRTN "QuEMolNa" (No. MRTN-CT-2003-504880) and the EC Network of Excellence "MAGMANet" (No. 515767-2).

\section{References}

1. Tanase S, Bouwman E. Adv Inorg Chem. 2006; 58:29.

2. Bruijnincx PCA, Van Koten G, Klein Gebbink RJM. Chem Soc Rev. 2008; 37:2716. [PubMed: 19020684] 
3. Costas M, Mehn MP, Jensen MP, Que L Jr. Chem Rev. 2004; 104:939. [PubMed: 14871146]

4. Solomon EI, Brunold TC, Davis MI, Kernsley JN, Lee SK, Lehnert N, Neese F, Skulan AJ, Yang YS, Zhou J. Chem Rev. 2000; 100:235. [PubMed: 11749238]

5. Tshuva EY, Lippard SJ. Chem Rev. 2004; 104:987. [PubMed: 14871147]

6. Wallar BJ, Lipscomb JD. Chem Rev. 1996; 96:2625. [PubMed: 11848839]

7. Bruijnincx PCA, Buurmans ILC, Gosiewska S, Moelands MAH, Lutz M, Spek AL, van Koten G, Klein Gebbink RJM. Chem Eur J. 2008; 14:1228. [PubMed: 18022966]

8. Dubois G, Murphy A, Stack TDP. Org Lett. 2003; 5:2469. [PubMed: 12841757]

9. Company A, Feng Y, Güell M, Ribas X, Luis J, Que L, Costas M. Chem Eur J. 2009; 15:3359. [PubMed: 19229926]

10. Feng Y, Ke C-y, Xue G, Que L. Chem Commun. 2008:50.

11. Gómez L, Garcia-Bosch I, Company A, Benet-Buchholz J, Polo A, Sala X, Ribas X, Costas M. Angew Chem Int Ed. 2009; 48:5720.

12. Schröder K, Enthaler S, Join B, Junge K, Beller M. Adv Synth Catal. 2010; 352:1771.

13. Gosiewska S, Lutz M, Spek AL, Klein Gebbink RJM. Inorg Chim Acta. 2007; 360:405.

14. Chen K, Costas M, Kim J, Tipton AK, Que L Jr. J Am Chem Soc. 2002; 124:3026. [PubMed: 11902894]

15. Chen K, Que L Jr. J Am Chem Soc. 2001; 123:6327. [PubMed: 11427057]

16. Roelfes G, Lubben M, Hage R, Que LJ, Feringa BL. Chem Eur J. 2000; 6:2152. [PubMed: 10926220]

17. van den Berg TA, de Boer JW, Browne WR, Roelfes G, Feringa BL. Chem Commun. 2004:2550.

18. Guajardo RJ, Hudson SE, Brown SJ, Mascharak PK. J Am Chem Soc. 193(115):7971.

19. Buchanan RM, Chen S, Richardson JF, Bressan M, Forti L, Morvillo A, Fish RH. Inorg Chem. 1994; 33:3208.

20. Xue G, De Hont R, Münck E, Que L. Nature Chem. 2010; 2:400. [PubMed: 20414242]

21. Ménage S, Vincent JM, Lambeaux C, Chottard G, Grand A, Fontecave M. Inorg Chem. 1993; 32:4766.

22. Terry TJ, Dubois G, Murphy A, Stack TDP. Angew Chem Int Ed. 2007; 46:945.

23. Bruijnincx PCA, Lutz M, Spek AL, Hagen WR, Weckhuysen BM, van Koten G, Klein Gebbink RJM. J Am Chem Soc. 2007; 129:2275. [PubMed: 17266307]

24. Bruijnincx PCA, Lutz M, Spek AL, van Faassen EL, Weckhuysen BM, van Koten G, Klein Gebbink RJM. Eur J Inorg Chem. 2005:779.

25. Braussaud N, Rüther T, Cavell KJ, Skelton BW, White AH. Synthesis. 2001; 4:626.

26. Lucas P, El Mehdi N, Ang Ho H, Bélanger D, Breau L. Synthesis. 2000; 9:1253.

27. Hagen KS. Inorg Chem. 2000; 39:5867. [PubMed: 11151391]

28. Duisenberg AJM, Kroon-Batenburg LMJ, Schreurs AMM. J Appl Cryst. 2003; 36:220.

29. Sheldrick, GM. Program for crystal structure refinement. University of Göttingen; Germany: 1997. SHELXL-97.

30. Spek AL. J Appl Cryst. 2003; 36:7.

31. Herbst-Irmer R, Sheldrick GM. Acta Cryst. 1998; B54:443.

32. Sheldrick, GM. TWINABS: Bruker-Nonius scaling and absorption correction for twinned crystals, V1.05. University of Göttingen; Germany: 2004.

33. Sheldrick, GM. Program for crystal structure solution. University of Göttingen; Germany: 1986. SHELXS-86.

34. Sheldrick, GM. SADABS: Area-Detector Absorption Correction, V2.10. University of Göttingen; Germany: 1999.

35. Altomare A, Burla MC, Camalli M, Cascarano GL, Giacovazzo C, Guagliardi A, Moliterni AGG, Polidori G, Spagna R. J Appl Cryst. 1999; 32:115.

36. Flack HD. Acta Cryst. 1983; A39:876.

37. Ardon M, Bino A, Michelsen K. J Am Chem Soc. 1987; 109:1986.

38. Byers PK, Canty AJ, Engelhardt LM, Patrick JM, White AH. J Chem Soc, Dalton Trans. 1985:981.

Inorg Chem. Author manuscript; available in PMC 2012 October 3. 
39. Crowder KN, Garcia SJ, Burr RL, North JM, Wilson MH, Conley BL, Fanwick PE, White PS, Sienerth KD, Granger RM II. Inorg Chem. 2004; 43:72. [PubMed: 14704055]

40. Knight JC, Amoroso AJ, Edwards PG, Prabaharan R, Singh N. Dalton Trans. 2010; 39:8925. [PubMed: 20714623]

41. Yang G, Zheng SL, Chen XM, Lee HK, Zhou ZY, Mak TCW. Inorg Chim Acta. 2000; 303:86.

42. Woltz J, Westcott BL, Crundwell G, Zeller M, Hunter AD, Sommerer SO. Acta Cryst. 2002; E58:m609.

43. Borer L, Thalken L, Ceccarelli C, Glick M, Zhang JH, Reiff WM. Inorg Chem. 1983; 22:1719.

44. Boudalis AK, Clemente-Juan JM, Dahan F, Psycharis V, Raptopoulou CP, Donnadieu B, Sanakis Y, Tuchagues JP. Inorg Chem. 2008; 47:11314. [PubMed: 18937442]

45. Nanda KK, Dutta SK, Baitalik S, Venkatsubramanian K, Kamalaksha N. J Chem Soc, Dalton Trans. 1995:1239.

46. Ou CC, Lalancette RA, Potenza JA, Schugar HJ. J Am Chem Soc. 1978; 100:2053.

47. Tanase S, Bouwman E, Long GJ, Shahin AM, Mills AM, Spek AL, Reedijk J. Eur J Inorg Chem. 2004:4572.

48. Thich JA, Ou CC, Powers D, Vasiliou B, Mastropaolo D, Potenza JA, Schugar HJ. J Am Chem Soc. 1976; 98:1425.

49. Zhu S, Brennessel WW, Harrison RG, Que L Jr. Inorg Chim Acta. 2002; 337:32.

50. Ghiladi M, Larsen FB, McKenzie CJ, Sotofte I, Tuchagues J-P. Dalton Trans. 2005:1687. [PubMed: 15852119]

51. Tanase S, Van Son M, Van Albeda GA, De Gelder R, Bouwman E, Reedijk J. Polyhedron. 2006; 25:2967.

52. Lee D, Du Bois J, Petasis D, Hendrich MP, Krebs C, Huynh BH, Lippard SJ. J Am Chem Soc. 1999; 121:9893.

53. Lee D, Lippard SJ. J Am Chem Soc. 1998; 120:12153.

54. Yoon S, Lippard SJ. J Am Chem Soc. 2004; 126:2666. [PubMed: 14995160]

55. Kahn, O. Molecular Magnetism. Wiley-VCH; New York: 1993.

56. Gorun SM, Lippard SJ. Inorg Chem. 1991; 30:1625.

57. Jullien J, Juhász G, Mialane P, Dumas E, Mayer CR, Marrot J, Rivière E, Bominaar EL, Münck E, Sécheresse F. Inorg Chem. 2006; 45:6922. [PubMed: 16903750]

58. This value was obtained for the optimized structure in the $S=5$ state; using the BS optimized structure yields a $J$ value that is slightly larger by $\sim 2 \mathrm{~cm}^{-1}$.

59. The energy of the complex is minimized at a fixed Fe-Fe distance with respect to the remaining internal coordinates in these calculations. The $0.06 \AA$ difference between the $\mathrm{H}-\mathrm{O}$ distances in $\{$ bare $\}$ and $\left\{\mathbf{1}\left(\mathrm{NO}_{3}\right)_{2}\right\}$ appears to have little effect on $J$.

60. Dawson JW, Gray HB, Hoenig HE, Rossman GR, Schredder JM, Wang RH. Biochemistry. 1972; 11:461. [PubMed: 5059123]

61. Oberhausen KJ, Richardson JF, O’Brien RJ, Buchanan RM, McCusker JK, Webb RJ, Hendrickson DN. Inorg Chem. 1992; 31:1123.

62. Shiemke AK, Loehr TM, Sanders-Loehr J. J Am Chem Soc. 1986; 108:2437.

63. Bénisvy L, Chottard J-C, Marrot J, Li Y. Eur J Inorg Chem. 2005:999.

64. Gorun SM, Lippard SJ. Inorg Chem. 1988; 27:149.

65. Guillot G, Mulliez E, Leduc P, Chottard JC. Inorg Chem. 1990; 29:579.

66. Kitajima N, Tamura N, Tanaka M, Moro-oka Y. Inorg Chem. 1992; 31:3342.

67. Stubna A, Jo D-H, Costas M, Brenessel WW, Andres H, Bominaar EL, Münck E, Que LJ. Inorg Chem. 2004:3067. [PubMed: 15132612]

68. Kryatov SV, Taktak S, Korendovych IV, Rybak-Akimova E, Kaizer J, Torelli S, Shan X, Mandal S, MacMurdo VL, Mairata i Payeras A, Que LJ. Inorg Chem. 2005; 44:85. [PubMed: 15627364]

69. Gejji SP, Hermansson K, Lindgren J. J Phys Chem. 1993; 97:3712.

70. Gosiewska S, Cornelissen JLM, Lutz M, Spek AL, van Koten G, Klein Gebbink RJM. Inorg Chem. 2006; 45:4214. [PubMed: 16676984]

71. Batten MP, Canty AJ, Cavell KJ, Rüther T, Skelton BW, White AH. Acta Cryst. 2004; C60:m316. 
72. Gütlich P, Garcia Y, Goodwin HA. Chem Soc Rev. 2000; 29:419.

73. Bousseksou A, Place C, Linares J, Varret F. J Magn Magn Mat. 1992; 104-107:225.

74. Britovsek GJP, Gibson VC, Spitzmesser SK, Tellmann KP, White AJP, Williams DJ. J Chem Soc, Dalton Trans. 2002

75. Evans DFJ. J Chem Soc. 1959:2003.

76. Buchen T, Gütlich P, Sugiyarto KH, Goodwin HA. Chem Eur J. 1996; 2:1134.

77. Gütlich P, Köppen H, Steinhäuser HG. Chem Phys Lett. 1980; 74:475.

78. Sorai M, Ensling J, Hasselbach KM, Gütlich P. Chem Phys. 1977:20.

79. Costas M, Chen K, Que LJ. Coord Chem Rev. 2000; 200-202:517.

80. Barton DHR, Boivin J, Motherwell WB, Ozbalik N, Schwartzentruber KM, Jankowski K. New J Chem. 1987; 10:387.

81. Gosiewska S, Permentier HP, Bruins AP, van Koten G, Klein Gebbink RJM. Dalton Trans. 2007:3365. [PubMed: 17664972]

82. Kojima T, Leising RA, Yan S, Que LJ. J Am Chem Soc. 1993; 115:11328.

83. Ménage S, Vincent JM, Lambeaux C, Fontecave M. J Mol Cat A. 1996; 113:61.

84. Nguyen C, Guajardo RJ, Mascharak PK. Inorg Chem. 1996; 35:6273.

85. Wang X, Wang S, Li L, Sundberg EB, Gacho GP. Inorg Chem. 2003; 42:7799. [PubMed: 14632495]

86. MacFaul PA, Arends IWCE, Ingold KU, Wayner DDM. J Chem Soc, Perkin Trans. 1997; 2:135.

87. MacFaul PA, Arends IWCE, Ingold KU, Wayner DDM, Que LJ. J Am Chem Soc. 1997; 119:10594.

88. Jensen MP, Costas M, Ho RYN, Kaizer J, Mairata i Payeras A, Münck E, Que LJ, Rohde J-U, Stubna A. J Am Chem Soc. 2005; 127:10512. [PubMed: 16045338]

89. White MC, Doyle AG, Jacobsen EN. J Am Chem Soc. 2001; 123:7194. [PubMed: 11459514]

90. Mas-Ballesté R, Fujita M, Hemmila C, Que LJ. J Mol Cat A. 2006; 251:49.

91. Chen K, Costas M, Que L Jr. J Chem Soc, Dalton Trans. 2002:672.

92. Groves JT, Gross Z, Stern MK. Inorg Chem. 1994; 33:5065.

93. Ryu JY, Kim J, Costas M, Chen K, Nam W, Que L Jr. Chem Commun. 2002:1288.

94. Chen K, Costas M, Kim J, Tipton AK, Que L Jr. J Am Chem Soc. 2003; 124:3026. [PubMed: 11902894] 
<smiles>c1ccc(CN(Cc2ccccn2)Cc2ccccn2)nc1</smiles>

tpa<smiles>Cn1ccnc1CN(Cc1nccn1C)Cc1nccn1C</smiles>

tmima

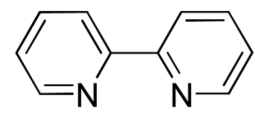

bipy<smiles>c1ccc(CN(Cc2ccccn2)C(c2ccccn2)c2ccccn2)nc1</smiles>

N4py<smiles>CN(CCN(C)Cc1ccccn1)Cc1ccccn1</smiles>

bpmen

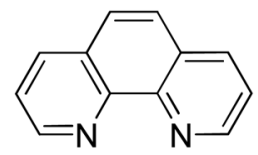

phen<smiles>NCCNCc1ncc(Br)c(C(=O)NCCc2c[nH]cn2)n1</smiles>

Hpma<smiles>Cn1ccnc1C(CC(=O)[O-])c1nccn1C</smiles>

L1

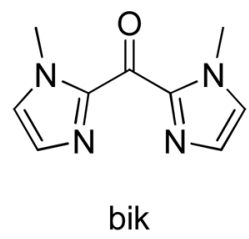

Figure 1.

Some selected ligands used in mono- and dinuclear non-heme iron oxidation catalysis, including the bik ligand used in this study. 


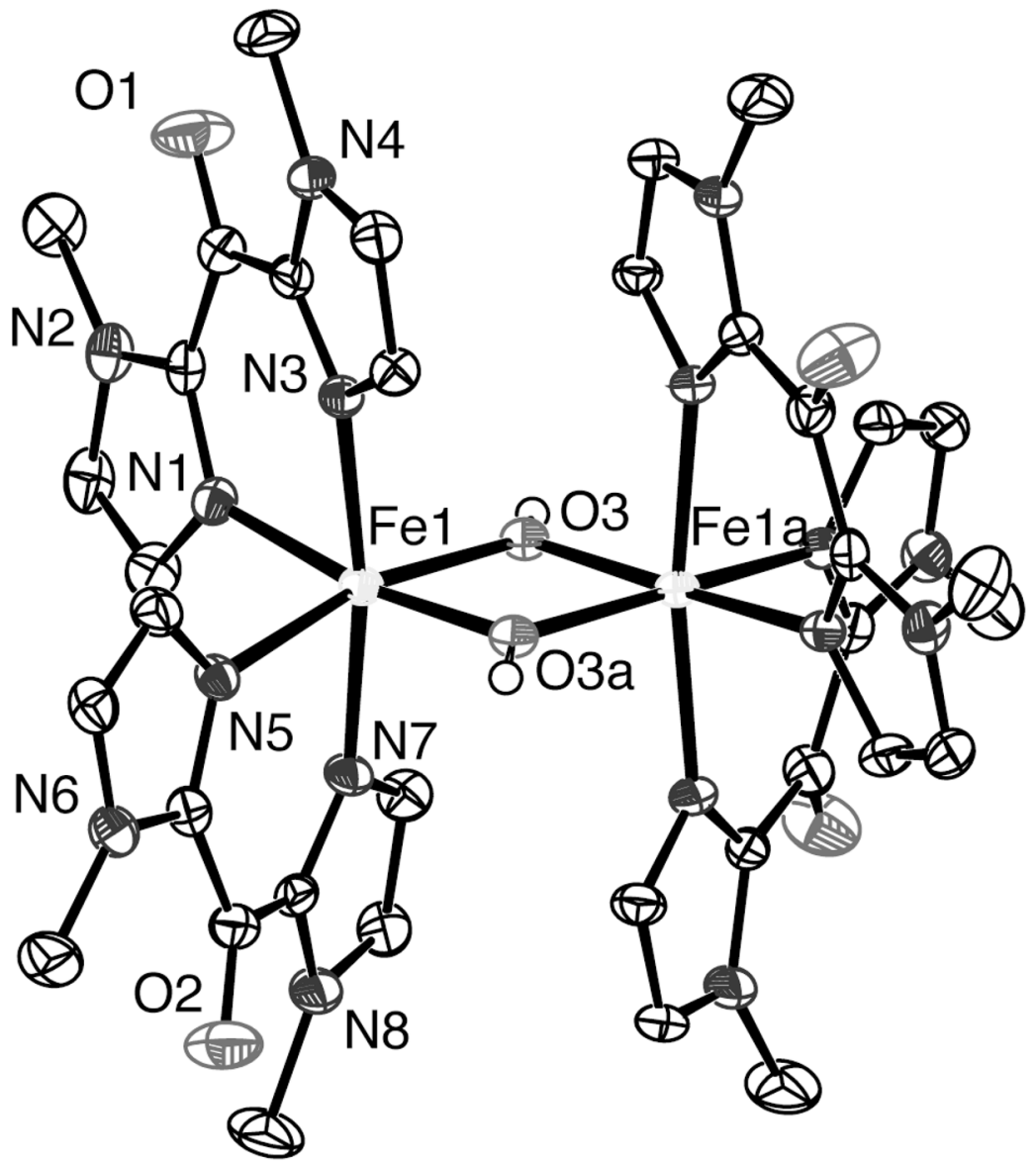

Figure 2.

Molecular structure of the dinuclear $\left[\mathrm{Fe}^{\mathrm{III}}{ }_{2}(\mu-\mathrm{OH})_{2}(\mathbf{b i k})_{4}\right]^{4+}$ cation of $\mathbf{1}$ in the crystal. All $\mathrm{C}-\mathrm{H}$ hydrogen atoms, nitrate anions and co-crystallized water molecules have been omitted for clarity. Displacement ellipsoids are drawn at the 50\% probability level. Symmetry operation a: 1-x, y, 1/2-z. 


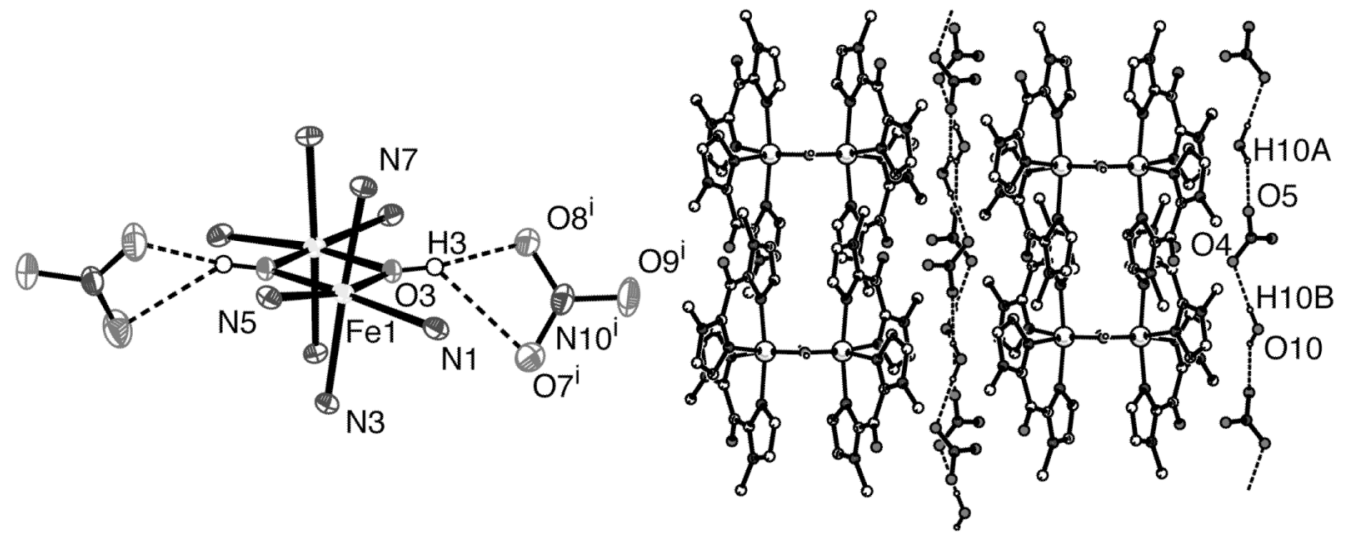

Figure 3.

Hydrogen bonding interactions in $\left[\mathrm{Fe}^{\mathrm{III}}{ }_{2}(\mu-\mathrm{OH})_{2}(\mathbf{b i k})_{4}\right]\left(\mathrm{NO}_{3}\right)_{4} \cdot 2 \mathrm{H}_{2} \mathrm{O}(\mathbf{1})$. Left: Hydrogen bonds between two nitrate anions and the $\left[\mathrm{Fe}^{\mathrm{III}}{ }_{2}(\mu-\mathrm{OH})_{2}(\mathbf{b i k})_{4}\right]^{4+}$ cation of $\mathbf{1}$. The $\mathrm{Fe}^{\mathrm{III}}{ }_{2}(\mu-$ $\mathrm{OH})_{2}$ core with donor atoms and the two hydrogen bonded nitrate anions are shown. Right: Hydrogen bonds resulting in infinite linear chains. Symmetry operation i: 1/2-x, 1/2-y, 1 $-\mathrm{z}$. 


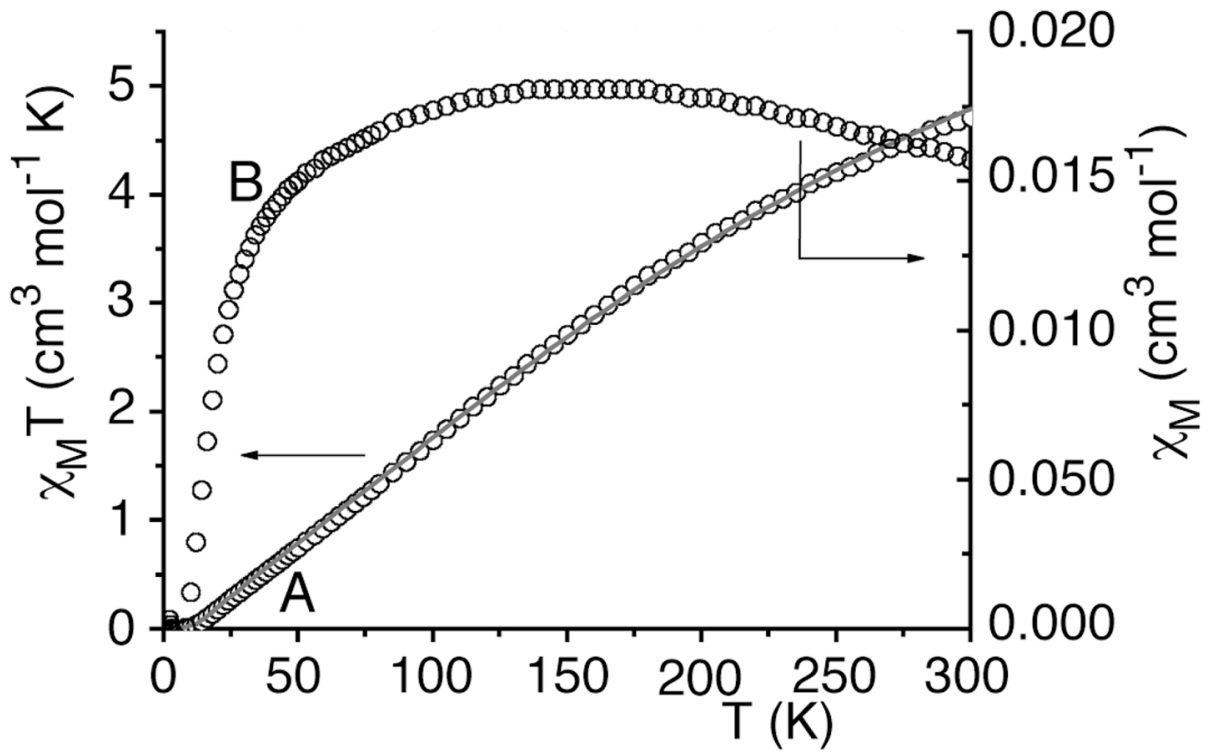

Figure 4.

Plots of $\chi_{M}$ T versus T (A) and $\chi_{M}$ versus T (B) for $\mathbf{1}$ from 2 to $300 \mathrm{~K}$ in $0.08 \mathrm{~T}$ field. 


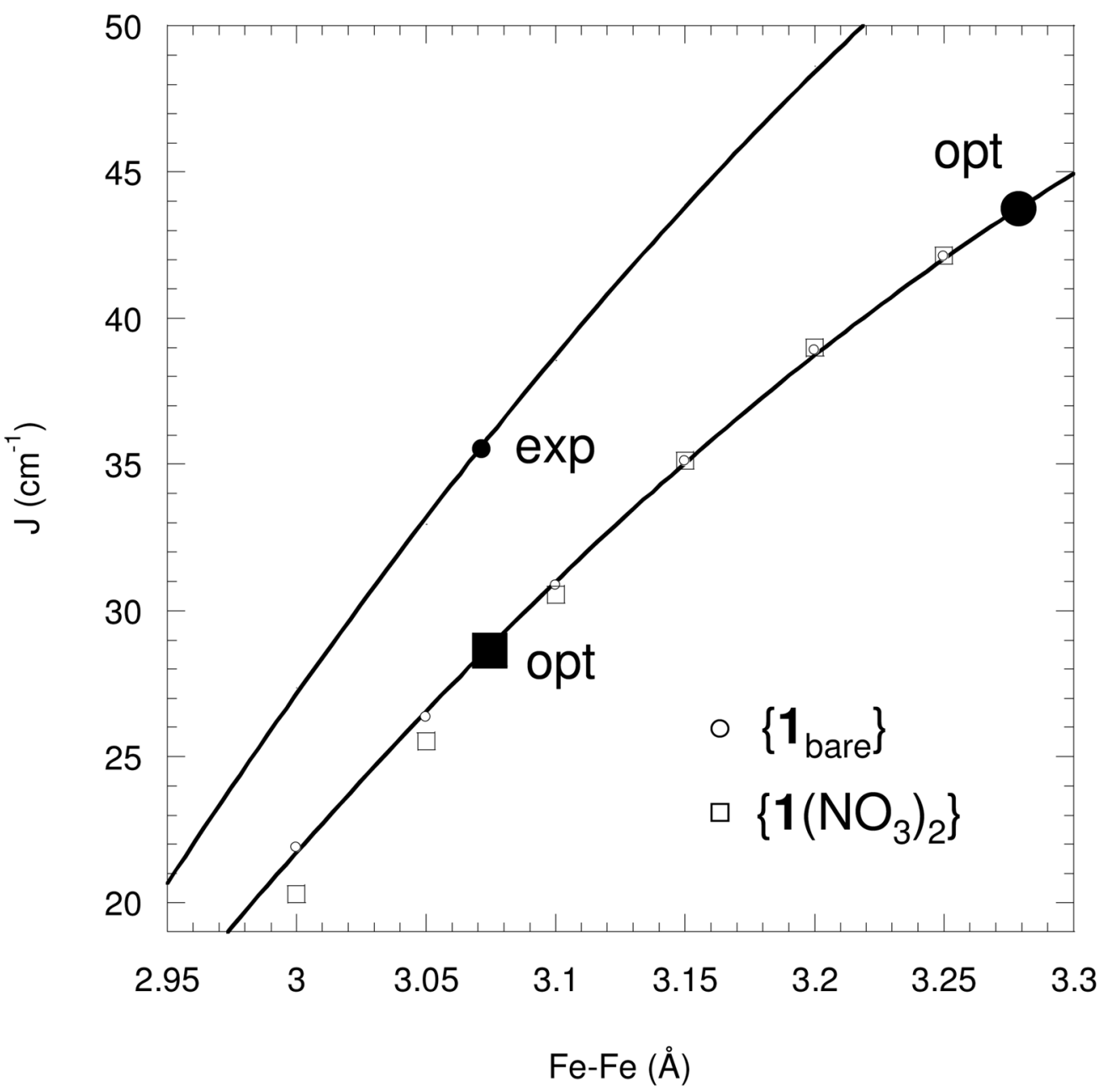

Figure 5.

Exchange-coupling constant $J$ for $\left\{\mathbf{1}_{\text {bare }}\right\}(\circ)$ and $\left\{\mathbf{1}\left(\mathbf{N O}_{3}\right)_{2}\right\}$ ( $\square$ ) calculated with relaxed DFT scans as a function of Fe...Fe distance. The solid circle and solid square labeled "opt" are the results for the optimized structures of $\left\{\mathbf{1}_{\text {bare }}\right\}$ and $\left.\left\{\mathbf{1}_{(\mathbf{N O}}\right)_{2}\right\}$. The experimental data point is labeled "exp". The upper curve is obtained from the curve though the data points for $\left\{\mathbf{1}_{\text {bare }}\right\}$ by multiplication with 1.25 . 


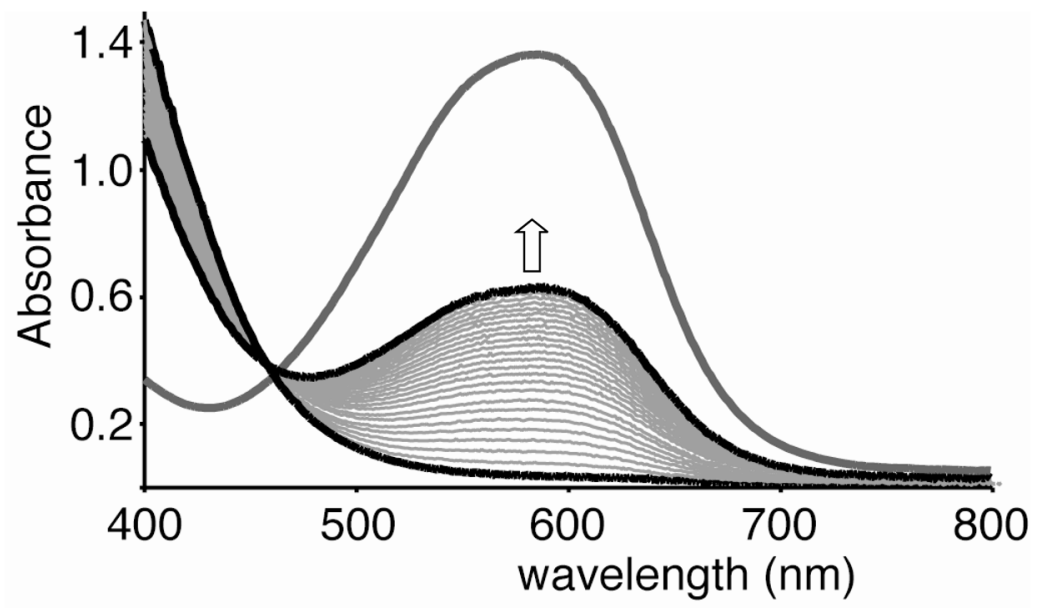

Figure 6.

UV-Vis spectral changes observed for $1(0.34 \mathrm{mM})$ in methanol at room temperature showing the formation of an $\left[\mathrm{Fe}^{\mathrm{II}}(\mathbf{b i k})_{3}\right]^{2+}$ species $(\mathrm{t}=120 \mathrm{~min})$. The $\mathrm{UV}-\mathrm{V}$ is spectrum of independently synthesized $\left[\mathrm{Fe}^{\mathrm{II}}(\mathbf{b i k})_{3}\right](\mathrm{OTf})_{2}(\mathbf{2})(0.3 \mathrm{mM})$ is included for comparison. 


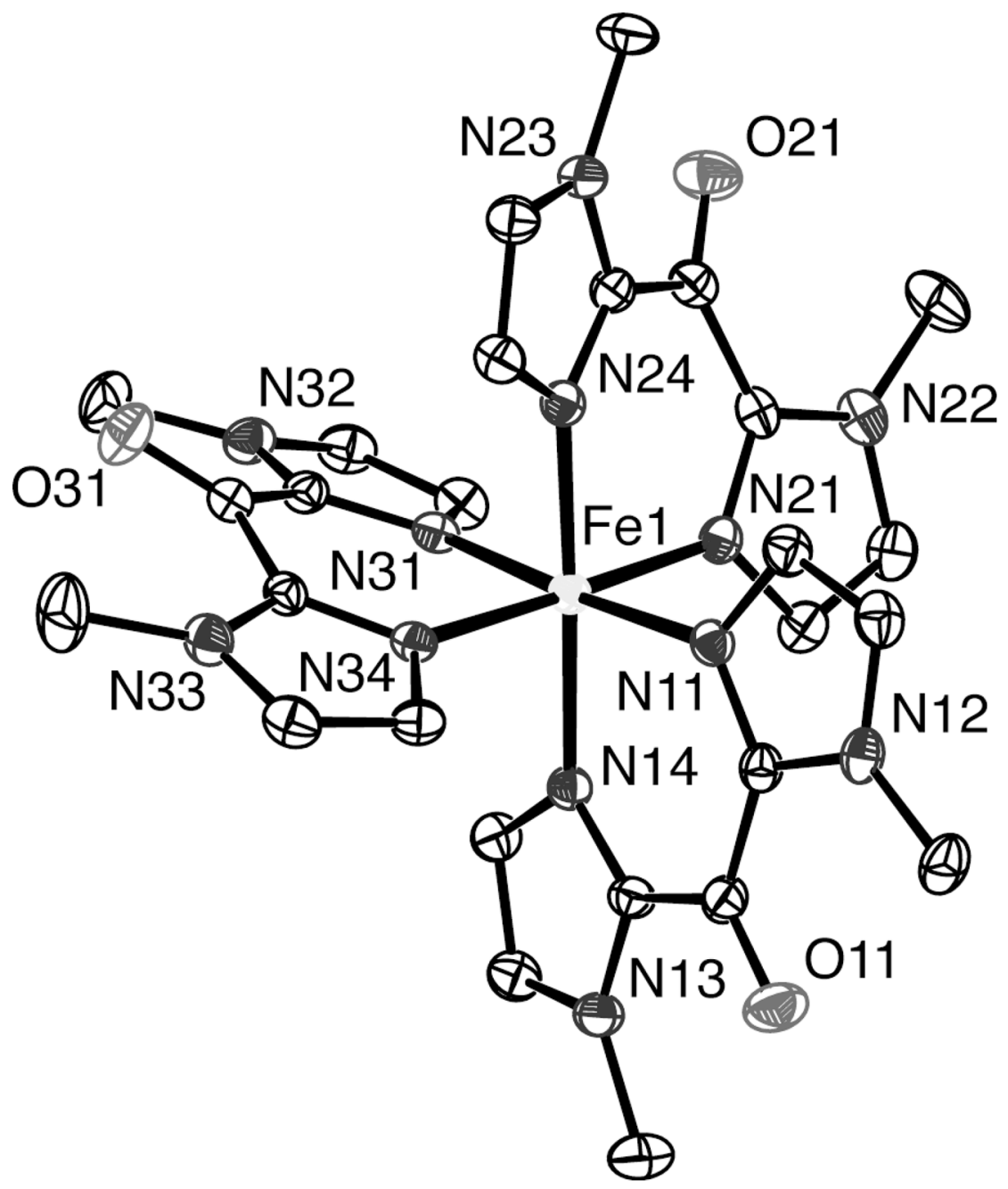

Figure 7.

Molecular structure of the $\left[\mathrm{Fe}^{\mathrm{II}}(\mathbf{b i k})_{3}\right]^{2+}$ cation in the crystal of $\mathbf{2} \cdot \mathbf{M e O H}$ at $150 \mathrm{~K}$ All hydrogen atoms, triflate anions and the co-crystallized methanol molecule have been omitted for clarity. Displacement ellipsoids are drawn at the 50\% probability level. 


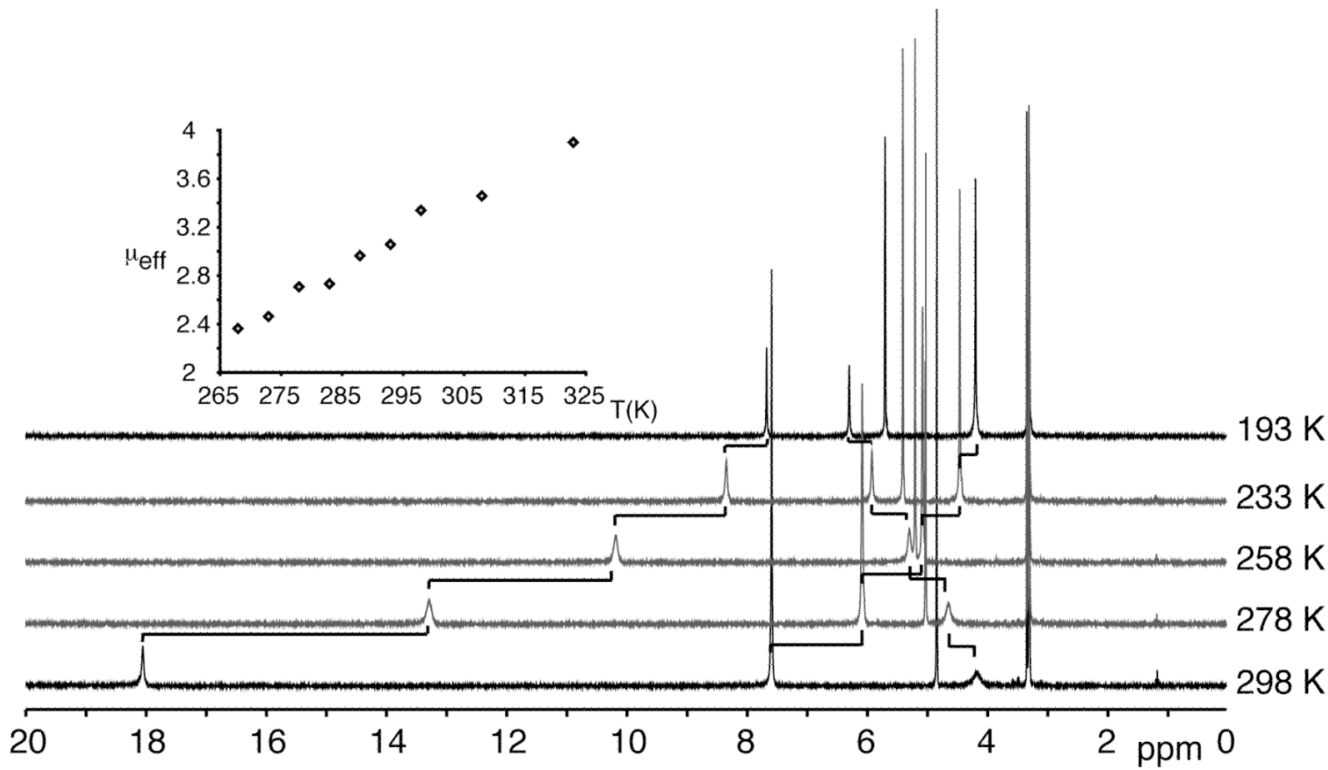

Figure 8.

${ }^{1} \mathrm{H}$ NMR spectral changes upon cooling a solution of $\left[\mathrm{Fe}^{\mathrm{II}}(\mathbf{b i k})_{3}\right](\mathrm{OTf})_{2}(2)$ in methanol- $d_{4}$. The inset shows the changes in the solution magnetic moment at various temperatures. 

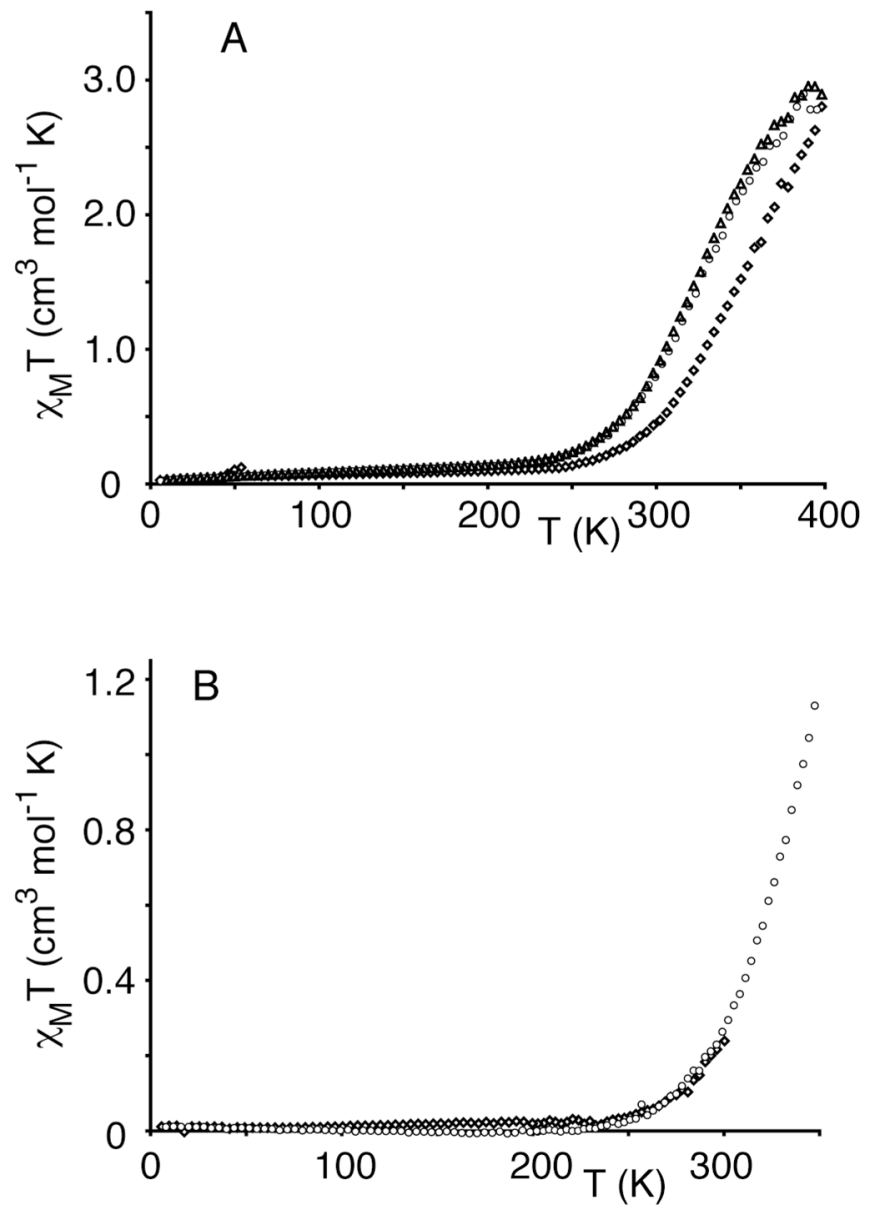

Figure 9.

Thermal variation of the $\chi_{\mathrm{M}} \mathrm{T}$ product of $\left[\mathrm{Fe}^{\mathrm{II}}(\mathbf{b i k})_{3}\right](\mathrm{OTf})_{2} \cdot \mathrm{MeOH}(\mathbf{2} \cdot \mathbf{M e O H}) . \mathrm{A}: \chi_{\mathrm{M}} \mathrm{T}$ versus T plot upon heating from $6 \mathrm{~K}$ to $400 \mathrm{~K}(\diamond)$, subsequent cooling $(\Delta)$, second heating (०). B: $\chi_{M} \mathrm{~T}$ versus $\mathrm{T}$ plot of $\mathbf{2} \cdot \mathbf{M e O H}$ when cooling first from room temperature to $6 \mathrm{~K}(\diamond)$ and back up again $(\circ)$. 


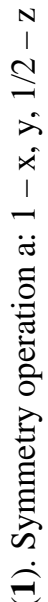

응

ণัن

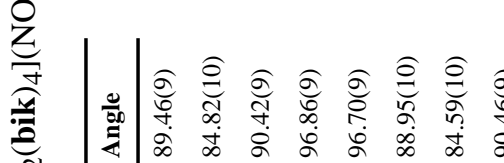

氙

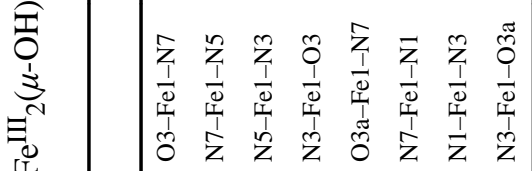

U.

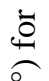

ఠ

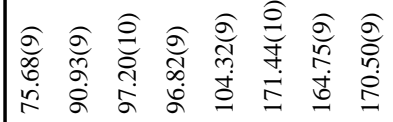

ỡ

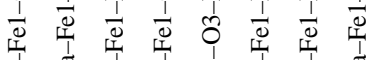

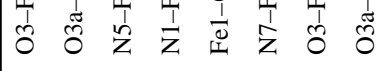

을

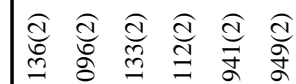

ڤิ)

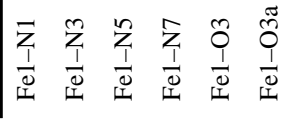




\section{Table 2}

Hydrogen bond lengths $(\AA)$ and angles $\left(^{\circ}\right)$ for $\left[\mathrm{Fe}^{\mathrm{III}}{ }_{2}(\mu-\mathrm{OH})_{2}(\mathbf{b i k})_{4}\right]\left(\mathrm{NO}_{3}\right)_{4} \cdot 2 \mathrm{H}_{2} \mathrm{O}(\mathbf{1})$. Symmetry operation i: $1 / 2-\mathrm{x}, 1 / 2-\mathrm{y}, 1-\mathrm{z}$, ii: $1 / 2-\mathrm{x}, 1 / 2+\mathrm{y}, 1 / 2-\mathrm{z}$

\begin{tabular}{lllll}
\hline Donor-H $\cdots$ Acceptor & D-H & H $\cdots$ A & D $\cdots \mathbf{A}$ & D-H $\cdots \mathbf{A}$ \\
\hline O3-H3A $\cdots$ O O $7^{\mathrm{i}}$ & $0.81(2)$ & $2.43(3)$ & $3.022(3)$ & $130(4)$ \\
O3-H3A $\cdots \mathrm{O}^{\mathrm{i}}$ & $0.81(2)$ & $1.82(2)$ & $2.623(3)$ & $171(4)$ \\
O10-H10A $\cdots$ O5 & $0.87(4)$ & $2.22(4)$ & $3.024(6)$ & $154(4)$ \\
O10-H10B $\cdots$ O $4^{\mathrm{ii}}$ & $0.85(3)$ & $2.05(3)$ & $2.903(6)$ & $176(3)$ \\
\hline
\end{tabular}


Table 3

Selected structural parameters and exchange coupling constant obtained from experiment and DFT geometry optimization and BS calculation with and without hydrogen bonds to nitrate

\begin{tabular}{|c|c|c|c|c|}
\hline & \multirow[t]{2}{*}{$\mathrm{X}$-ray crystal structure } & \multicolumn{2}{|c|}{ DFT (optimized) } & \multirow[t]{2}{*}{ Magnetic susceptibility measurements } \\
\hline & & $\left\{\mathbf{1}_{\text {bare }}\right\}$ & $\left\{1\left(\mathrm{NO}_{3}\right)_{2}\right\}$ & \\
\hline $\mathrm{Fe} \cdots \mathrm{Fe}(\AA)$ & $3.0723(6)$ & 3.281 & 3.078 & \\
\hline $\mathrm{Fe}-\mathrm{O}-\mathrm{Fe}\left({ }^{\circ}\right)$ & 104.32(9) & 107.5 & 103.0 & \\
\hline $\mathrm{Fe}-\mathrm{O}(\AA)$ & 1.941(2) and 1.949(2) & 2.034 & 1.966 & \\
\hline $\mathrm{H}-\mathrm{O}(\AA)$ & $0.815(19)$ & 0.969 & 1.024 & \\
\hline$J\left(\mathrm{~cm}^{-1}\right)$ & & 43.7 & 28.4 & 35.9 \\
\hline
\end{tabular}


Table 5

Oxidation of adamantane catalyzed by $\left[\mathrm{Fe}(\mathbf{b i k})_{3}\right](\mathrm{OTf})_{2}(\mathbf{2})$ with $t-\mathrm{BuOOH}^{a}$

\begin{tabular}{lllll}
\hline Conditions & adamant-1-ol $^{b}$ & adamant-2-ol $^{\boldsymbol{b}}$ & adamant-2-one $^{\boldsymbol{b}}$ & $\mathbf{3}^{\circ} / \mathbf{2}^{\circ} \boldsymbol{c}$ \\
\hline acetonitrile, air & 20.6 & 0.3 & 2.8 & 19.9 \\
acetonitrile, $\mathrm{N}_{2}$ & 15.0 & n.d. ${ }^{d}$ & 2.0 & 22.5 \\
acetone, air & 23.7 & n.d. & 2.4 & 29.6 \\
\hline
\end{tabular}

$a_{\text {For reaction conditions: see experimental section. }}$

${ }^{b}$ Yields expressed as turnover numbers $(\mathrm{TON}=\mathrm{mol}$ product $/ \mathrm{mol}$ catalyst $)$.

$c_{3 \%} / 2^{\circ}=3^{*}($ TON adamant-1-ol)/(TON adamant-2-ol + TON adamant-2-one $)$.

$d_{\text {Not detected. }}$ 
Table 6

Oxidation of alkanes by $\left[\mathrm{Fe}^{\mathrm{II}}(\mathbf{b i k})_{3}\right](\mathrm{OTf})_{2}(\mathbf{2})$ with $t-\mathrm{BuOOH}^{a}$

\begin{tabular}{|c|c|c|c|}
\hline Substrate & Product & TON $^{b}$ & Remarks \\
\hline \multirow[t]{2}{*}{ cyclohexane } & cyclohexanol (A) & 10.4 & acetonitrile, air \\
\hline & cyclohexanone (K) & 16.9 & $\mathrm{~A} / \mathrm{K}=0.6$ \\
\hline \multirow[t]{2}{*}{ cyclohexane } & cyclohexanol & 4.0 & acetone, air \\
\hline & cyclohexanone & 6.4 & $\mathrm{~A} / \mathrm{K}=0.6$ \\
\hline \multirow[t]{2}{*}{ cyclohexane } & cyclohexanol & 4.0 & acetonitrile, $\mathrm{N}_{2}$ \\
\hline & cyclohexanone & 5.7 & $\mathrm{~A} / \mathrm{K}=0.7$ \\
\hline \multirow[t]{2}{*}{ ethylbenzene } & 1-phenylethanol & 21.5 & acetonitrile, air \\
\hline & acetophenone & 57.9 & $\mathrm{~A} / \mathrm{K}=0.4$ \\
\hline \multirow[t]{2}{*}{ ethylbenzene } & 1-phenylethanol & 0.2 & acetonitrile, $\mathrm{N}_{2}$ \\
\hline & acetophenone & 1.7 & \\
\hline \multirow[t]{2}{*}{ cis-1,2-dimethylcyclohexane $^{d}$} & $c i s-1,2-\mathrm{ol}$ & 2.2 & acetonitrile, air \\
\hline & trans-1,2-ol & 1.3 & $\mathrm{RC}=27 \% c$ \\
\hline \multicolumn{4}{|c|}{ For reaction conditions: see experimental section. } \\
\hline
\end{tabular}

Inorg Chem. Author manuscript; available in PMC 2012 October 3. 
Table 7

Oxidation of alkenes catalyzed by $\left[\mathrm{Fe}(\text { bik })_{3}\right](\mathrm{OTf})_{2}(\mathbf{2})$ with $\mathrm{H}_{2} \mathrm{O}_{2}{ }^{a}$

\begin{tabular}{|c|c|c|c|c|}
\hline \multirow[t]{2}{*}{ Substrate } & \multicolumn{2}{|c|}{ Epoxide $(\mathrm{TON})^{b}$ (dropwise addition of $\mathrm{H}_{2} \mathrm{O}_{2}$ ) } & \multicolumn{2}{|c|}{ Epoxide (TON) $)^{b}$ (addition of $\mathrm{H}_{2} \mathrm{O}_{2}$ at once } \\
\hline & 1 hour & 7 hours & 1 hour & 7 hours \\
\hline cyclooctene & 6.8 & 14.7 & 6.9 & 14.1 \\
\hline styrene $^{c, d}$ & $7.7(5.7)$ & $14.5(6.1)$ & $7.3(5.9)$ & $12.8(5.9)$ \\
\hline 1-octene & 3.4 & 7.0 & 3.2 & 6.5 \\
\hline cyclohexene $^{d, e}$ & $2.0(15.6 / 13.8)$ & $2.8(24.2 / 17.6)$ & $1.8(17.2 / 14.7)$ & $2.6(22.3 / 15.3)$ \\
\hline trans-2-heptene $f$ & $5.6[93]$ & $13.5[91]$ & $5.8[88]$ & $12.7[94]$ \\
\hline cis-2-heptene $f$ & $6.7[62]$ & $16.9[77]$ & $7.1[64]$ & $17.1[77]$ \\
\hline
\end{tabular}

$a_{\text {For reaction conditions: see experimental section. }}$

${ }^{b}$ Yields expressed as turnover numbers $(\mathrm{TON}=\operatorname{mol}$ product $/ \mathrm{mol}$ catalyst $)$.

${ }^{c}$ Value in brackets is the observed TON for benzaldehyde formation.

$d_{\text {Reactions done under } \mathrm{N}_{2} \text { atmosphere. }}$

${ }^{e}$ Values in brackets are the observed TONs for 2-cyclohexen-1-ol and 2-cyclohexen-1-one, respectively.

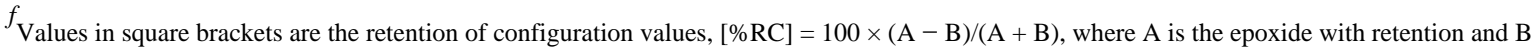
is the epimer. 


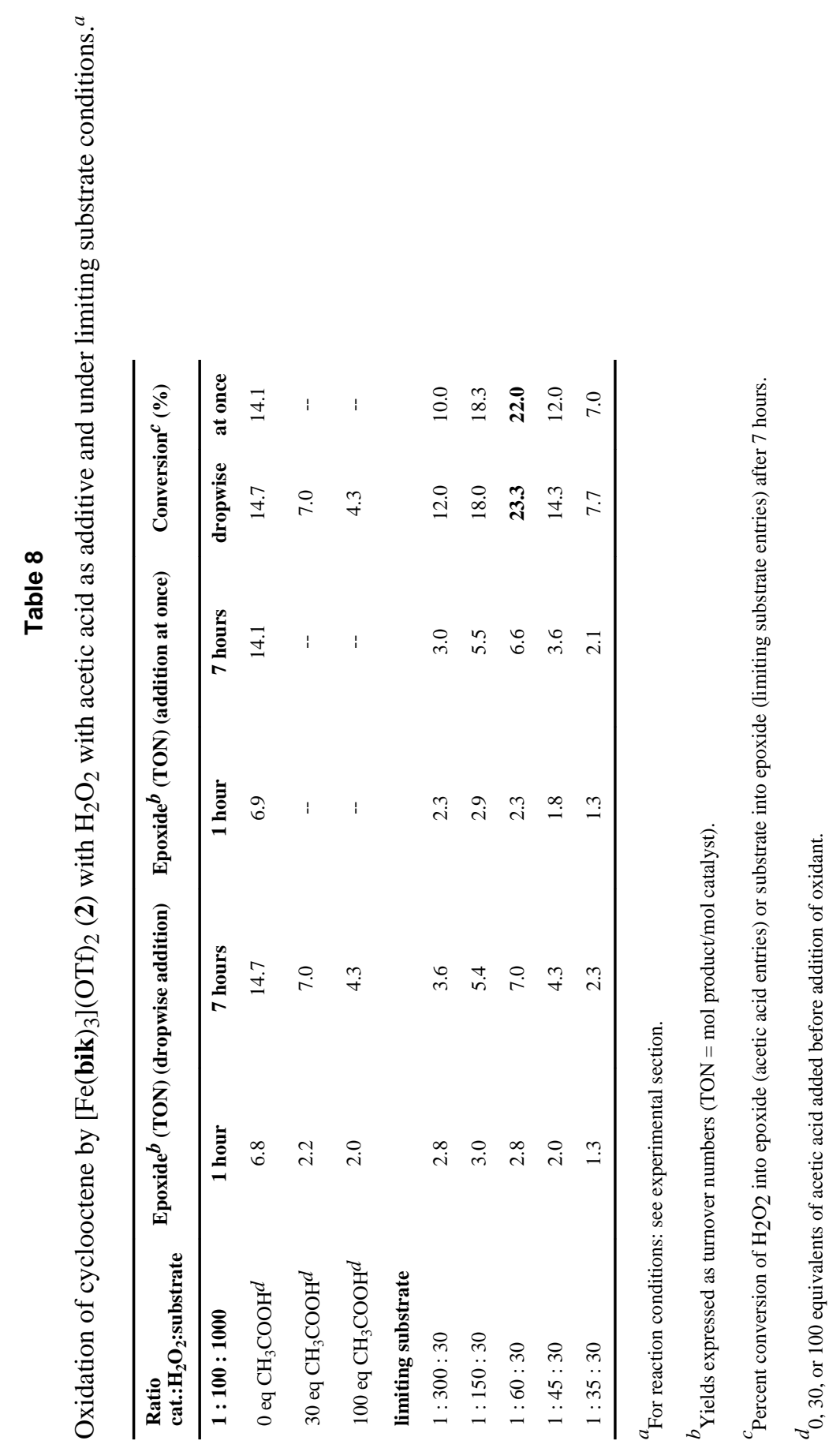

